\author{
И.В. Филимонов ${ }^{1}$, А.А. Янковская ${ }^{1}$, С.В. Кужелко ${ }^{1}$, В.В. Завьялов ${ }^{1}$, Н.В. Завьялова ${ }^{1}$,
} А.Н. Голипад ${ }^{1}$, Д.П. Колесников ${ }^{1}$, В.А. Ковтун ${ }^{1}$, В.И. Холстов ${ }^{1}$, И.В. Лягин ${ }^{2}$,

\author{
Е.Н. Ефременко²
}

${ }^{1}$ Федеральное государственное бюджетное учреждение "27 Научный иентр» Министерства обороны Российской Федерации, 105005, Российская Федерация, г. Москва, Бригадирский пер., д. 13

${ }^{2}$ Московский государственный университет имени М.В. Ломоносова, химический факультет, 119234, Российская Федерация, г. Москва, Ленинские Горы, д. 1, стр. 3

Поступила 07.05.2018 г. Принята к публикации 05.06.2018 г.

В статье представлен обзор теоретических и экспериментальных исследований, проведенных отечественными и зарубежными учеными, по изучению ферментов как в нативном состоянии, так и в виде химически стабилизированных наноразмерных частиц, перспективных для использования в области создания изделий военного назначения различного типа. Обобщены результаты по использованию биокатализаторов на основе ферментов и микроорганизмов-деструкторов для нейтрализации экотоксикантов. Рассмотрена природа ферментов. Проанализированы данные, полученные в сфере химико-биологических и медицинских биокаталитических технологий, по созданию ферментных лечебно-профилактических средств. Отдельное внимание уделено ферментам, используемым в качестве компонентов средств защиты, биокатализаторам для очистки окружающей среды от токсичных химикатов, биопрепаратам на основе ферментов и микроорганизмов-деструкторов для утилизации реакционных масс, химической детоксикации отравляющих веществ. Осуществлен выбор направлений дальнейших исследований по использованию нанобиотехнологий: ферментные препараты для профилактики и лечения поражений отравляющими веществами; ферменты в составе самодегазирующихся материалов в качестве компонентов средств защиты; биокатализаторы для очистки почвы, воды и поверхностей; биопрепараты на основе ферментов и микроорганизмов-деструкторов для деградации реакционных масс отравляющих веществ.

Ключевые слова: бактерии Pseudomonas sp. 78Г; биокатализаторы для очистки окружающей среды; гексагистидин-содержащая органофосфатгидролаза Нis -ОФГ; микроорганизмы-деструкторы токсичных химикатов; самодегазирующиеся материалы; ферментные антидоты ФОВ; ферментные катализаторы деструкции реакционных масс ФОВ; ферментные компоненты средств зациты; ферменты-катализаторы химических реакций в организме; фосфорорганические отравляющие вещества ФОВ.

Библиографическое описание: Филимонов И.В., Янковская А.А., Кужелко С.В., Завъялов В.В., Завьялова Н.В., Голипад А.Н., Колесников Д.П., Ковтун В.А., Холстов В.И., Лягин И.В., Ефременко Е.Н. Исследования в сфере перспективного использования химико-биологических и медицинских биокаталитических технологий в интересах Вооруженных Сил // Вестник войск РХБ защйты. 2018. T. 2. № 2. С. 18-50. 
Reseach in the Sphere of Perspective Use of Biochemical and Medical Biocatalytic Technologies...

\section{СОДЕРЖАНИЕ}

Природа ферментов

Использование биокатализаторов на основе ферментов и микроорганизмов-деструкторов для нейтрализации экотоксикантов

I Современные разработки по созданию антидота ФОС на основе ферментов

II Ферменты в качестве компонентов средств защиты

III Биокатализаторы для очистки окружающей среды

IV Биопрепараты на основе ферментов и микроорганизмов-деструкторов для утилизации реакционных масс, полученных путем химической детоксикации отравляющих веществ

Направления исследований перспективного использования биопрепаратов в интересах

Изучение и использование ферментных препаратов в нативном состоянии и в виде химически стабилизированных наноразмерных частиц ведутся во всем мире уже несколько десятилетий. Число публикаций о биокаталитических системах на основе ферментов и клеток микроорганизмов увеличивается с каждым годом.

Однако недостаток научных фундаментальных знаний о кинетических закономерностях, лежащих в основе функционирования биокаталитических систем, является сдерживающим фактором широкого применения на практике биокатализаторов - препаратов на основе ферментов и микроорганизмов-деструкторов.

Целью настоящей работы является обзор результатов фундаментальных и прикладных исследований, проведенных отечественными и зарубежными учеными, по изучению ферментов (ферментных препаратов), выбор направлений дальнейших исследований по перспективам использования нанобиотехнологий при создании изделий военного назначения различного типа.

\section{Природа ферментов}

Ферменты, или энзимы, представляют собой белковые молекулы или молекулы РНК, либо их комплексы, которые катализируют химические реакции в биологических системах, не подвергаясь при этом химическим превращениям. Они способствуют перевариванию и распаду жиров, белков, сокращению мышц и проведению нервных импульсов в живых системах как животного, так и растительного происхождения; ускоряют окислительно-вос- создания изделий военного назначения различного типа

1 Ферментные антидоты

2 Ферменты в составе самодегазирующихся материалов в качестве компонентов средств защиты

3 Биокатализаторы для очистки окружающей среды

4 Биопрепараты на основе ферментов и микроорганизмов-деструкторов для утилизации реакционных масс отравляющих веществ

Заключение

Информация о конфликте интересов

Сведения о рецензировании статьи

Список источников

становительные, гидролитические, синтетические и многие другие биохимические процессы во всех живых клетках. Нехватка или избыток необходимых ферментов негативно сказывается на функциональной активности и жизнеспособности организма.

По строению ферменты могут быть как однокомпонентными - простыми белками, так и сложными - содержащими несколько разных белковых субъединиц и небелковую часть. Некоторые ферменты входят в состав плазматической мембраны клеток, другие находятся и работают внутри клеток, третьи секретируются клетками и выходят в межклеточное пространство органов и тканей, попадают в кровеносную и лимфатическую системы или просвет желудка, тонкой и толстой кишки.

Субстратом называется химическое вещество, подвергающееся превращению под действием фермента. Реагенты - вещества, участвующие в химической реакции, но при этом не являющиеся объектом обработки. Реакционный (активный) центр - атом, у которого происходит разрыв или образование связей. Коферменты (коэнзимы, кофакторы) - молекулы небелковой природы, специфически соединяющиеся с соответствующими белками и играющие роль активного центра. Регуляторы каталитической активности: активаторы - повышают, ингибиторы - понижают активность ферментов. Продукты реакции - образующиеся в ходе реакции вещества.

Ферменты специфичны к субстратам. Эффективность их действия чрезвычайно высока. Одна молекула фермента может катализировать превращение до $10^{6}$ молекул субстрата в минуту. 
И.В. Филимонов, А.А. Янковская, С.В. Кужелко и др.

В зависимости от условий, ферменты способны катализировать как прямую, так и обратную реакцию.

Подобно всем белкам, ферменты лабильны и после денатурации оказываются неактивными. Активность ферментов в клетке непостоянна во времени. Ферменты чутко реагируют на ситуацию, в которой оказывается клетка, на факторы, воздействующие на нее как снаружи, так и изнутри. Такая чувствительность ферментов к изменениям окружающей среды позволяет клетке приспособиться к новым условиям, дать должный ответ на гормональные и иные стимулы, а в некоторых ситуациях предоставить клетке шанс выжить.

Для изучения свойств ферментов обычно их получают путем выделения из тканей животных, растений, клеток или культуральной жидкости, накапливающейся при выращивании микроорганизмов, биологических жидкостей [1-4].

Использование биокатализаторов на основе ферментов и микроорганизмов-деструкторов для нейтрализации экотоксикантов

Утилизация многих вредных для здоровья и опасных для жизни веществ, уже присутствующих или попадающих (вносимых) в окружающую среду, составляет комплекс важных экологических, социальных, экономических и научных проблем. Задача деструкции нейротоксичных фосфорорганических соединений (ФОС), к числу которых относятся применяемые в сельском хозяйстве пестициды (хлорпирифос, метилпаратион, параоксон, малатион), а также продукты детоксикации боевых отравляющих веществ (зарина, зомана, вещества типа VX), является наиболее значимой, поскольку сотни тысяч тонн этих веществ, произведенных в последние полвека, представляют серьезную экологическую угрозу при хранении, уничтожении, а в случае пестицидов - при их использовании.

В США ежегодно производится 620 тыс. пестицидов, в странах Европейского Союза - 320 тыс., в России 100 тыс. В то же время не существует эффективной и приемлемой для окружающей среды технологии утилизации этих веществ, в том числе в случае аварийных ситуаций (розливов, развалов и т.п.) $[5,6]$.

Детоксикация различных ФОС с помощью биокаталитических систем имеет ряд преимуществ, а именно: она проходит в мягких условиях (при отсутствии резко щелочных условий среды, повышенных температур, агрессивных химических агентов), при этом продукты гидролиза, как правило, являются биологически деградируемыми. В качестве биока- тализаторов особый интерес представляют различные ферменты, гидролизующие ФОС. Было установлено, что на сегодняшний день наиболее высокоэффективно действующим ферментом для биодеструкции ФОС является органофосфатгидролаза (ОФГ, ЕС 3.1.8.1, арилдиалкилфосфатаза), катализирующая гидролиз эфирной связи в триэфирах ортофосфорной и фосфоновой кислот $[5,6]$.

Для решения различных задач по детоксикации ФОС была проведена направленная генетическая модификация органофосфатгидролазы, обеспечивающая существенное упрощение выделения фермента из клеток, продуцирующих его, и создание систем для его многократного использования в виде стабилизированных иммобилизованных препаратов $[7,8]$. Введение гексагистидиновой последовательности на $\mathrm{N}$-конец молекулы ОФГ позволило, помимо основной цели модификации фермента, увеличить в несколько раз гидролитическую активность этого фермента ( is $_{6}-\mathrm{O} Ф$ ) по отношению к субстратам, содержащим P-S связь (например, хлорпирифос, малатион, VX и т.д.) в сравнении с исходным вариантом фермента $[9,10]$. Поэтому для разработки рецептуры, нейтрализующей ФОС, целесообразным представляется использование именно генетически модифицированного фермента His - -ОФГ, схема которого представлена на рисунке 1.

Проведенный рентгеноструктурный анализ ОФГ $[11,12]$ показал, что шесть остатков гистидина находятся непосредственно вблизи активного центра фермента, а четыре из этих остатков (His-55, His-57, His-201 и His-230) являются лигандами ионов металла в активном центре фермента (изображены на рисунке 2).

Два иона металла связаны друг с другом посредством карбамилированного остатка Lys-169. В апоформе фермента остаток Lys-169 не модифицирован. При помощи ${ }^{13} \mathrm{C}$ ЯМР-спектроскопии было доказано, что в образовании карбамилированного остатка Lys принимает участие диоксид углерода. Установлено, что высокая концентрация бикарбоната, привнесенная в раствор фермента, ускоряет процесс формирования его активного центра при переходе апоформы в холоформу в присутствии ионов металла [13].

Вторым мостиковым лигандом между ионами металла служит молекула воды (рисунок 2). Таким образом, для поддержания и/или эффективного функционирования активного центра фермента необходимо присутствие в реакционной среде при гидролизе ФОС воды и карбонат-ионов. Также необходимо отметить, что именно в карбонатном буфере при рН 10 наблюдается проявление максимума каталитической активности у фермента 
Исследования в сфере перспективного использования химико-биологических и медицинских...

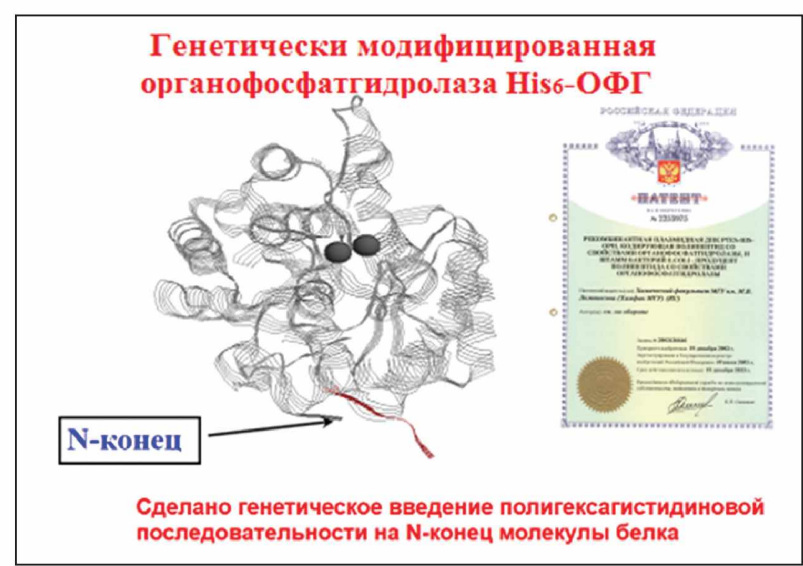

Рисунок 1 - Фермент генетически модифицированная органофосфатгидролаза - His 6 -ОФГ

His $_{6}-\mathrm{OФГ} \mathrm{[9].} \mathrm{В} \mathrm{этой} \mathrm{связи} \mathrm{целесообразным,}$ в том числе и с экономической точки зрения, представляется использование при работе с модифицированным ферментом именно карбонатной буферной системы.

Кроме этого, показано, что при длительном хранении и использовании биокатализаторов на основе His -ОФГ для предотвращения инактивации фермента необходима его стабилизация путем иммобилизации. Такая стабилизация фермента может быть достигнута за счет применения различных подходов $[14,15]$. Одной из наиболее современных технологий иммобилизации ферментов является микрои нанокапсулирование, например, путем комплексообразования с полимерами, создающими вокруг фермента защитную оболочку, в результате чего фиксируется каталитически активная конформация молекулы фермента, которая оказывается защищенной от негативных воздействий окружающей среды, а при этом сами комплексы представляют собой микроили наноразмерные частицы [16]. Такой подход может быть использован для разработки новых лечебно-профилактических антидотов и биокатализаторов на основе ферментов.

I Современные разработки по созданию антидота ФОС на основе ферментов

За последние 20 лет удалось добиться значительных успехов в изучении противодействия отравлениям ФОС, но классические фармакологические подходы уже достигли оптимального уровня. В медицинской практике, в основном, применяются средства антидотной терапии поражений фосфорорганическими токсикантами.

В качестве профилактических средств защиты ацетилхолинэстеразы (АХЭ) от воздействия фосфорорганических токсикантов используют гетероциклические обратимые ингибиторы, в частности, галантамин, пири-

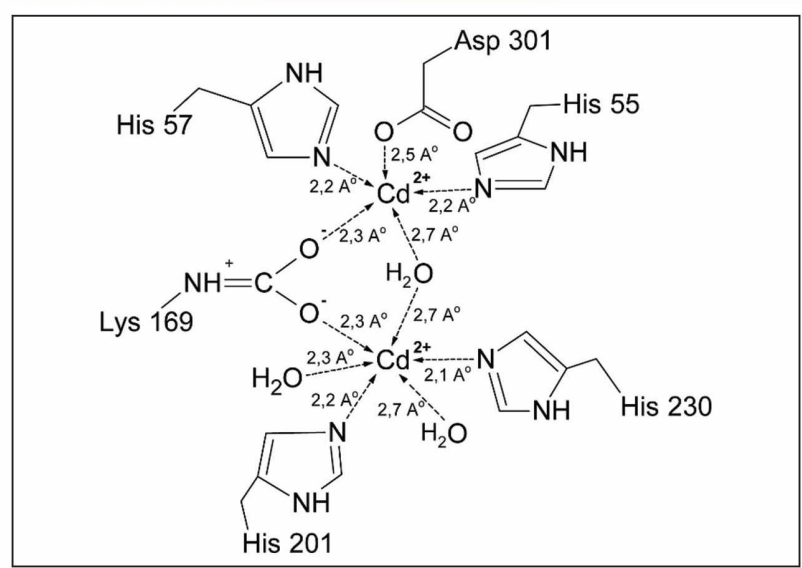

Рисунок 2 - Строение активного чентра ОФГ, образованного при участии ионов $\mathrm{Cd}^{2+}[13]$

достигмин и др. Однако их длительное применение или использование в больших количествах опасно для здоровья [17].

Анализ применяемых в настоящее время медикаментозных антидотных средств против отравления ФОС, включая ФОВ, показал, что все имеющиеся в настоящее время антидоты обладают рядом недостатков: собственной токсичностью и, соответственно, малыми допустимыми дозами; серьезными побочными эффектами (в том числе в отношении нервной системы и органов чувств, сердечно-сосудистой системы и желудочно-кишечного тракта и пр.); противопоказаниями и ограничениями по применению.

Созданные специалистами МГУ имени M.B. Ломоносова (нано)-биокаталитические ферментные препараты на основе $\mathrm{His}_{6}-\mathrm{O} Ф$, будучи веществами биологической природы, обладают высокоспецифичным действием, не приводят к состояниям интоксикации и могут быть оптимальным решением для борьбы с отравлениями ФОС.

Разработка ферментных антидотов, выполняющих роль «биочистильщиков» кровотока, действие которых основано на каталитическом гидролизе непосредственно ФОС, является одним из наиболее перспективных новых направлений совершенствования средств медицинской защиты от воздействия нейротоксинов.

В качестве (нано)-биокатализаторов гидролиза ФОВ сегодня за рубежом исследуются рекомбинантная человеческая ацетилхолинэстераза (АХЭ), бутирилхолинэстераза (БХЭ), параоксоназа, пролидаза и фосфотриэстераза (ФТЭ) [17]. Однако по эффективности своего каталитического действия эти ферменты на несколько порядков уступают российскому (нано)биокатализатору - гексагистидин-содержащей органофосфатгидролазе (His $-\mathrm{O} Ф Г$ ), проявляющей широкий субстратный спектр 


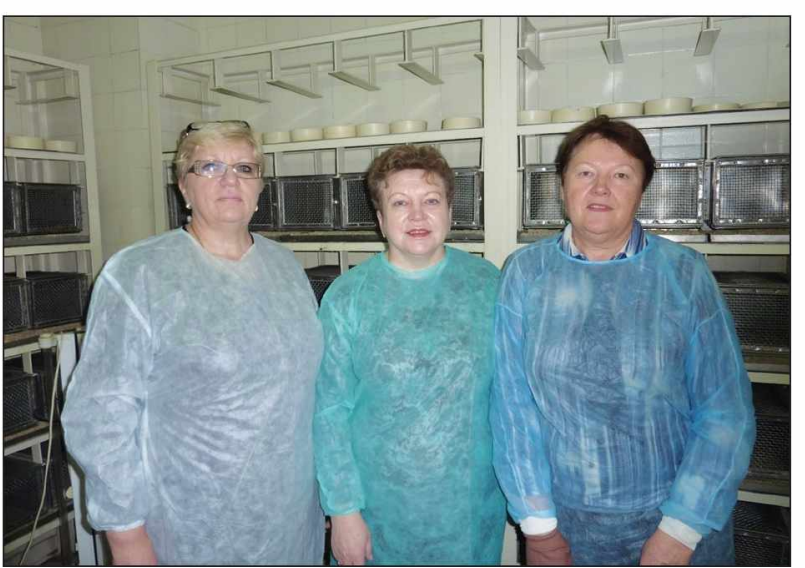

Рисунок 3 - Группа специалистов 27 НЦ МО РФ (главный научный сотрудник доктор биологических наук профессор Н.В. Завьялова, старший научный сотрудник кандидат биологических наук Н.А. Колосова, научный сотрудник Н.В. Перевозчикова) - участники эксперимента по изучению гидролитической активности образцов ферментных нанопрепаратов в отношении ФОС (nестицидов)

действия в реакциях гидролитического разложения ФОВ и пестицидов in vivo.

Оригинальные формы российского фермента, полученные в результате его стабилизации в фермент-полиэлектролитных комплексах, представляют собой наночастицы размером $\sim 40$ нм, с высокой активностью органофосфатгидролазы и значительно улучшенной стабильностью (при хранении, как минимум, 1,5 года при $25^{\circ} \mathrm{C}$ - потеря активности не более $10 \%$ ).

Иммобилизация обеспечивает им надежную защиту от воздействия пептидаз крови, длительную циркуляцию в крови при отсутствии формирования иммунного ответа, а также продолжительное сохранение ими каталитической активности. Такой (нано)биокаталитический препарат представляет собой разработку нового поколения антидотов ФОС и ФОВ, и может быть использован как терапевтическое средство при поражении, а также в качестве средства профилактической защиты при заблаговременном его введении в организм.

Специалистами 27 НЦ МО РФ (рисунок 3) образцы (нано)-биокаталитических препаратов были апробированы на белых крысах in vivo. Было установлено, что гидролитические нанопрепараты не вызывают иммунной реакции при введении их в кровь лабораторных животных и длительно циркулируют в крови (эффективная активность обнаруживается до 15 ч), разрушая вещество типа VX и различные пестициды.

При внутривенном, внутрибрюшинном, внутримышечном или трансбуккальном вве- дении (представлены на рисунке 4) препаратов в качестве профилактического средства (введение за 60 мин до отравления пестицидами) они обеспечивали $100 \%$ выживание животных даже при их интоксикации двукратной смертельной дозой ФОС $\left(2 \times \mathrm{LD}_{100}\right)$ и $50 \%$ выживание животных при трехкратной смертельной дозе ФОС $\left(3 \times \mathrm{LD}_{100}\right)$. В спучае применения тех же (нано)-биокатализаторов в качестве терапевтического средства в течение 10-15 мин после интоксикации смертельной дозой ФОС $\left(\mathrm{LD}_{100}\right)$ их однократное внутривенное введение было достаточным для обеспечения 100 \% выживания животных.

Такие препараты могут иметь большое значение для ликвидации и предотвращения интоксикации людей и животных фосфорорганическими соединениями. Так как коммерческих аналогов таких антидотов в мире не описано, то представляется целесообразным продолжить исследования в данном направлении совместно со специалистами ФМБА РФ.

Полученные результаты опубликованы в журнале Journal of Controlled Release [18] и могут быть основой для создания нового поколения средств индивидуальной и коллективной защиты войск и населения при ведении боевых действий, совершении террористических актов и в условиях техногенных аварий. Результаты могут быть полезны как ВС РФ, так и специализированным службам, занимающимся устранением загрязнений ФОС, в том числе аварийных, утилизацией ФОС на различных объектах, а также специальной обработкой средств индивидуальной защиты и ВВСТ, решением вопросов безопасности персонала и населения России.

Необходимо отметить, что разработка первых наноразмерных препаратов началась более 30 лет назад, и уже в 1990-е гг. на рынке появились первые нанопрепараты для лечения рака. Первые такие нанозимы были основаны на липосомах - сферических полых включениях, имеющих один или несколько липидных бислоев.

В конце 1980-х гг. группа под руководством профессора Казунори Катаоки из Университета Токио (Япония) стала использовать полимерные мицеллы для доставки маленьких молекул. В 2006 г. лекарство на основе полимерных мицелл, созданное корейской компанией Самьянг, было разрешено к использованию.

В России группа ученых химического факультета МГУ имени М.В. Ломоносова под руководством профессора Александра Кабанова исследовала адресную доставку в организм ферментов, способных разрушать токсичные фосфорорганические соединения, с помощью нанопрепаратов. 
Reseach in the Sphere of Perspective Use of Biochemical and Medical Biocatalytic Technologies...

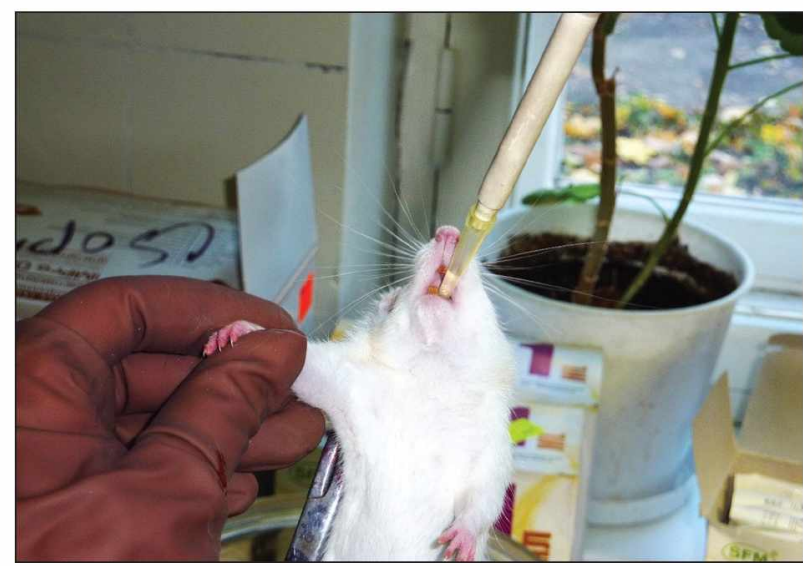

A

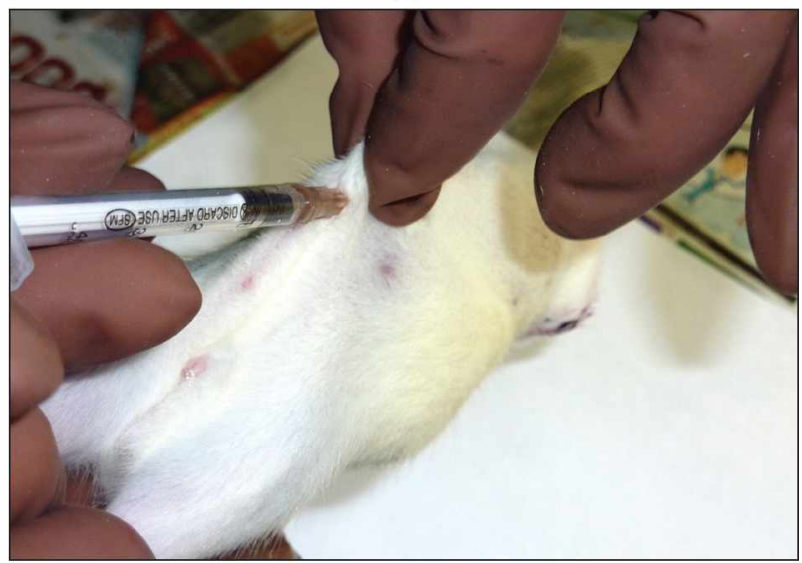

B

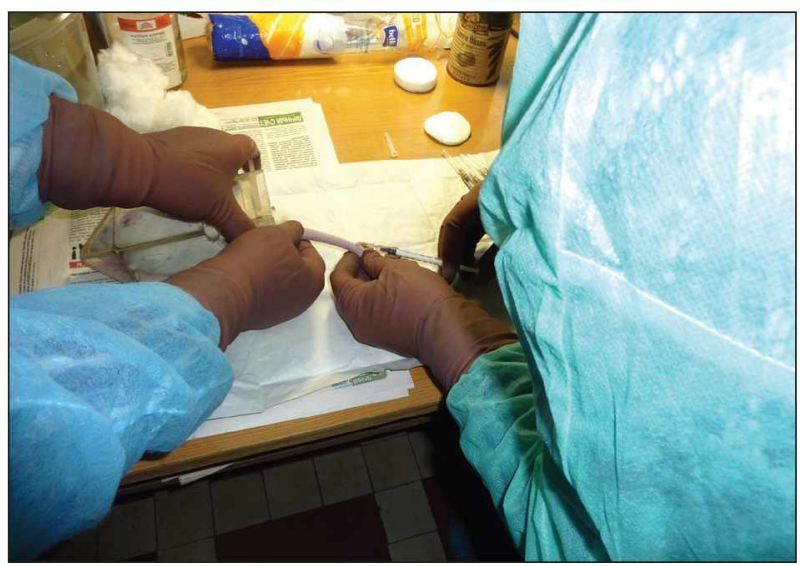

B

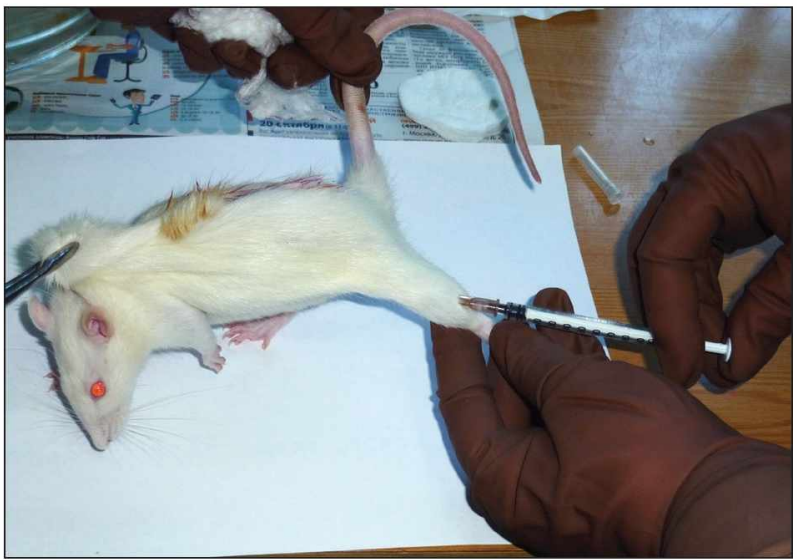

Г

Рисунок 4 - Эксперимент по использованию (нано)биокаталитического препарата - фермента $\mathrm{His}_{6}-О Ф Г$ в качестве антидота ФОС

( А - трансбуккальное; Б - внутривенное; В - внутрибрюшинное; $Г$-внутримышечное введение)

Основу этих препаратов составляет разработанный в лаборатории экобиокатализа МГУ под руководством доктора биологических наук профессора Елены Ефременко химически модифицированный фермент органофосфатгидролаза His -ОФГ и биоразлагаемый полимер на основе одной из аминокислот (глутаминовой кислоты). Важным является простота подхода: нанопрепарат органофосфатгидролазы His -ОФГ получается простым смешиванием водных растворов высокоочищенного фермента и безопасного биосовместимого полимера. Этот нанопрепарат самособирается за счет электростатических взаимодействий между белком (ферментом) и полимером [16].

Надо отметить, что одним из первых метод подобной стабилизации белков применила группа исследователей под руководством профессора А.В. Кабанова в 1994 г. в Медицинском центре Университета Небраски в Омахе (США), которая занималась созданием ферментных полимерных комплексов, формирующихся за счет электростатических взаимодействий на основе разных биомолекул. Изначально химиков интересовало использование мицелл для до- ставки молекул РНК и ДНК, позднее ученые активно занялись использованием этого подхода для доставки белков, в частности ферментов, в центральную нервную систему.

В настоящее время множество лабораторий по всему миру работают в данной области, применяя самые различные подходы для создания подобных наноразмерных препаратов.

В 2010 г. уже был получен большой задел в направлении создания и доставки ферментных нанопрепаратов для «улучшения» ферментов с целью их дальнейшего медицинского применения. В качестве доставляемого фермента была выбрана органофосфатгидролаза His-ОФГ, которая может расщеплять токсичные пестициды и боевые ФОВ. Однако ее недостатком оставался слабый иммунный ответ при введении в организм млекопитающих, а также относительно невысокая стабильность и быстрое выведение из организма.

Химики решили эту проблему, применив «сборочный» подход: в результате включения фермента органофосфатгидролазы $\mathrm{His}_{6}-\mathrm{O} Ф Г$ в нанопрепарат снижается иммунный ответ, существенно увеличивается стабильность фер- 
мента при хранении и увеличивается время его циркуляции в крови после введения в организм. В экспериментах на крысах было показано, что препарат эффективно защищает организм от летальных доз высокотоксичных пестицидов и даже боевого отравляющего вещества VX [18].

Простота и технологичность подхода в сочетании с полученными результатами на животных делают этот препарат привлекательным для клинического применения [19].

За рубежом также проводились исследования по разработке антидотов на основе ферментов [20]. Исследования на животных (мышах, крысах, мини-свиньях) и людях проводились с использованием рекомбинантной ацетилхолинэстеразы PRX-105, которая была получена из генетически модифицированной линии клеток растений Nicotiana tabacum в качестве антидота при поражении фосфонатами-пестицидами и отравляющими веществами (зоман, VX). Исследованная рекомбинантная ацетилхолинэстераза PRX-105 была произведена фирмой «Protalix Biotherapeutics» (Кармиэль Израиль).

Авторы исследования вводили рекомбинантную ацетилхолинэстеразу PRX-105 за 2 мин внутривенно с последующим введением только животным поражающей дозы 1,3-1,5 $\times \mathrm{LD}_{50}$ фосфоната-DEPQ (7-[(diethoxyphosphinyl) oxyl]-1-methylquinolinium methyl sulfate), имитирующего VX. По утверждению авторов, все животные выжили. Гибель животных в контрольной группе, которой не вводили PRX-105, наступала через 60-90 с после интоксикации.

Согласно полученным данным, исследование на людях (десяти добровольцах) по внутривенному введению 0,9 мг/мл активного вещества PRX-105 в физиологическом растворе $(0,9 \% \mathrm{NaCl})$ было проведено впервые. DEPQ в данном случае не применяли. Рекомбинантную ацетилхолинэстеразу PRX $10^{5}$ все добровольцы перенесли хорошо. Ответную аллергическую реакцию на фермент не наблюдали [20].

К настоящему времени российскими и зарубежными учеными предложен ряд новых принципов создания профилактических антидотов ФОВ $[17,21-23]$. Одним из них является стратегия защиты АХЭ, состоящая в модификации активного центра (АЦ) фермента путем селективного связывания с циклическими лигандами, которые блокируют прохождение молекул фосфорорганических токсикантов к АЦ фермента, но не влияют на его ферментативную активность по отношению к ацетилхолину [21-23].

Методом молекулярного моделирования были раскрыты широкие перспективы создания циклических соединений, получены мутанты АХЭ, которые могут быть использованы для реализации предлагаемой стратегии создания эффективного антидота [22].

Еще одним новым направлением создания профилактических антидотов является нейтрализация действия ФОВ путем снижения его концентрации в кровяном русле, при использовании антидотов-«биоловушек», которые предотвращают перенос токсичных молекул к физиологическим мишеням [21]. Исследования в этом направлении интенсивно проводятся в США, Франции и России.

Поскольку бутирилхолинэстеразы (БХЭ) в организме человека содержится значительно больше, чем АХЭ, они имеют близкие структуры активного центра и специфичные субстраты, а также являются мишенью для одних и тех же токсичных соединений, поэтому принято считать, что БХЭ может защищать АХЭ от соединений антихолинэстеразного действия путем их связывания с образованием фермент-ингибиторного комплекса с последующим необратимым ингибированием фермента в случае взаимодействия c $Ф$ ОВ.

БХЭ не вызывала до последнего времени особого интереса, пока министерство обороны США не ассигновало миллион долларов на массовое производство очищенного препарата БХЭ человека для защиты от ФОВ. Исследования на животных (полевых мышах) показали, что использование БХЭ в качестве антидота полностью защищало их от 5 доз $\mathrm{LD}_{50}$ ФОВ. В данном случае БХЭ выступала в роли антидота-«биоловушки» [21].

Оценка эффективности влияния свежезамороженной плазмы крови на терапевтические эффекты, полученные у пациентов при отравлении ФОВ, показала, что терапия плазмой крови может быть эффективным альтернативным или вспомогательным методом печения [21].

Для массового производства БХЭ были разработаны два промышленных процесса. Первый - в США, основанный на очистке природного фермента плазмы крови человека. Однако выход такой очищенной БХЭ был низкий - из одного литра плазмы получали около 1 мг БХЭ. После этого в 2006 г. высокоочищенная БХЭ была объявлена FDA (Food and Drug Administration FDA) новым исследуемым лекарством для обеспечения защиты от ФОВ в США [24].

Второй процесс был разработан фирмой Nexia в Канаде. В этом процессе использовался рекомбинантный фермент человека, продуцируемый в молоке трансгенных коз. Выход рекомбинантной БХЭ по этой технологии значительно выше. Начиная с 2006 г., фирма «Pharmatheme» в Мэриленде, США, 
разрабатывает производные этого рекомбинантного фермента [25].

Интерес также представляют результаты совместных исследований российских и зарубежных ученых по созданию рекомбинантной БХЭ в качестве антидота ФОВ [26]. Проведенная модификация БХЭ позволила авторам создать устойчивые в кровотоке «биоловушки», которые длительное время защищали мышей против 4,2 доз $\mathrm{LD}_{50}$ вещества VX.

Принцип действия каталитических «биоловушек» основан на идее непрерывного захвата и разложения ФОВ в кровотоке еще до достижения ими центральной, периферической и нервно-мышечной систем ферментами, модифицированными сайт-направленным мутагенезом [26].

К числу наиболее ранних работ, посвященных оценке перспективы детоксикации ФОВ с использованием рекомбинантных ферментов - каталитических «биоловушек», относятся исследования, выполненные в Медицинском научно-исследовательском институте Химической защиты армии США $[27,28]$.

На основе результатов компьютерного моделирования и сайт-направленного мутагенеза с заменой аминокислоты в полипептидной цепи активного центра БХЭ получены мутанты по аминокислотным остаткам G117H и G117K, устойчивые к ингибированию зарином и VX. Также компьютерным моделированием дополнительно был получен мутант E197G, а путем двойного замещения был получен мутант G117H/E197G, который проявляет две запрограммированные функции: совмещает очень низкую скорость «старения» фосфорилированного мутанта E197Q с ускорением дефосфорилирования мутанта G117H. Мутант G117H/ E197Q способен катализировать гидролиз зарина, VX и всех четырех стереоизомеров зомана [28]. Однако его каталитическая активность была слишком слаба, чтобы представлять фармацевтический интерес.

Мутант БХЭ - G117H был идентифицирован как перспективная каталитическая «биоловушка» с улучшенной активностью против зарина, но не удовлетворял требованиям к клиническому использованию. Поэтому исследователями были созданы еще более 60 двойных и тройных мутантов человеческой БХЭ с мутантом G117H и мутантов человеческой АХЭ. Однако ни один из этих мутантов не был активнее мутанта G117H по отношению к зарину и VX.

Для получения более активной каталитической ловушки были проведены исследования по изучению механизма достижения мутантом G117Н каталитической активности против такого сильного ФОВ, как зарина, а также определены значения свободных энергий для спонтанной реактивации природной БХЭ и ее мутанта $\mathrm{G} 117 \mathrm{H}$, фосфорилированных зарином [29].

Работы по компьютерному моделированию, направленному мутагенезу, квантово-механическим расчетам и получению новых вариантов мутантов БХЭ продолжаются и в настоящее время. Авторы исследований приходят к заключению о перспективности использования, с точки зрения фармацевтического применения, главным образом, только рекомбинантных ферментов [21, 30].

Таким образом, анализ литературных данных позволяет сделать заключение о перспективности использования рекомбинантных ферментов бактериального происхождения и холинэстераз для решения ключевых проблем в области защиты от пестицидов и фосфорорганических соединений нервнопаралитического действия, в том числе от боевых отравляющих веществ.

II Ферменты в качестве компонентов средств защиты

В данном направлении ведутся интенсивные исследования как в США, так и в России. Наиболее эффективными в составе средств индивидуальной защиты являются материалы, в состав которых входят как химические, так и биологические (иммобилизованные ферменты) - катализаторы деструкции ФОВ.

В литературе описаны эффективные защитные материалы, в состав которых в качестве сорбентов и одновременно катализаторов разложения ФОВ входят оксиды металлов $[31,32]$ или комплексные соли металлов [33].

Такие защитные материалы при контакте с VX или зоманом в концентрации

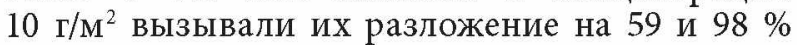
соответственно, за 24 ч. Однако использование этих катализаторов приводит к значительному удорожанию самих защитных материалов, поскольку эффективный гидролиз достигается лишь при высоком содержании катализаторов и высокой степени их измельчения.

Альтернативой химическим катализаторам, вводимым в защитные фильтрующесорбирующие самодегазирующиеся материалы, могут составить ферменты, способные высокоспецифично катализировать гидролиз токсичных веществ.

Преимущества фильтрующе сорбирующих материалов на основе ферментов обусловлены тем, что скорости разложения ФОВ под действием, например, органофосфатгидролазы, превышают скорости реакций, катализируемых химическими реагентами [13], и при этом одинаковая степень конверсии ФОВ достигается при существенно меньших коли- 
чествах ферментов, чем в реакциях с химическими катализаторами [6].

Считается, что наиболее целесообразно использовать ферменты в иммобилизованной форме, которая обеспечивает длительное сохранение каталитической активности ферментов и упрощает процедуру их введения в структуру защитных материалов [6]. Кроме того, ферменты в иммобилизованной форме в составе материалов гарантируют не только достаточно сильную сорбцию и удерживание $\Phi О В$, но и осуществляют их разложение (дегазацию)

В СШІА разработан фильтрующе-сорбирующий материал, представляющий собой полиуретановую губку, содержащую ковалентно-иммобилизованную органофосфатгидролазу и частицы активированного угля [34].

Включение активного угля в сорбент и иммобилизация фермента осуществляется непосредственно в процессе полимеризации и формирования полиуретанового носителя. Максимальная концентрация фермента в составе та-

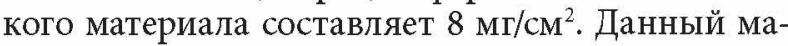
териал предназначен для детоксикации зарина, зомана и VX в составе средств индивидуальной защиты, однако из открытой печати пока известны лишь результаты его успешного применения только в отношении фосфорорганических пестицидов [35-39].

Другой фильтрующе-сорбирующий самодегазирующийся защитный материал состоит из трех слоев [40].

Верхний слой выполнен из полипропилена, поликарбоната или бутилкаучука. Этот слой, контактирующий, в случае поражения, с каплями токсичных веществ, предотвращает проникание жидкой фазы веществ во внутренние слои материала и обеспечивает равномерный подвод их паров к внутренним слоям материала.

Средний слой, предназначеный для сорбции паров токсичных веществ и их дегазации, состоит из резины или вспененного пластика с импрегнированными частицами активированного угля, фермента фосфорилфосфатазы и йодбензойной кислоты.

Нижний слой, непосредственно прилегающий к кожному покрову, представляет собой целлюлозосодержащий материал.

Недостатком данного защитного материала является ограничение его каталитической активности из-за наличия резины или вспененного пластика, что не способствует удерживанию в микроокружении фермента воды, необходимой для гидролиза [6].

В последние годы появились технологии получения текстильных материалов, в которых все чаще внедряются специальные отделочные препараты, пропитки и обработки тканей различными наноразмерными покрытиями.

В России также разработан фермент-содержащий материал, предназначенный для использования в составе средств индивидуальной защиты от ФОВ. Действие данного материала основано на одновременной абсорбции и детоксикации (гидролизе) ФОВ под действием иммобилизованного фермента $\mathrm{His}_{6}-\mathrm{O} Ф$ в нативной форме.

В качестве носителя для физической иммобилизации фермента используется сорбент на основе акрилата Stochosorb 500 Powder, который обладает колоссальной абсорбционной емкостью и способен удерживать большие объемы сорбируемых веществ, увеличивая свою массу до 3000 раз [41].

При нанесении на поверхность разработанного фильтрующе-сорбирующего самодегазирующегося материала вещества типа VX, зомана или зарина в концентрации $10 \mathrm{\Gamma} / \mathrm{M}^{2}$ происходит нейтрализация паров ФОВ при температуре до $45{ }^{\circ} \mathrm{C}$ на $100 \%$ за 3-7 ч при рН 7,8-10,5, и гарантируется отсутствие паров токсичных химикатов за слоем защитного материала на протяжении не менее 96 часов. Данный материал сохраняет свои защитные свойства на $100 \%$ после его хранения в герметичной упаковке до $12 \mathrm{mec} \mathrm{[41].}$ На рисунке 5 представлена схема защитного материала на основе иммобилизованного фермента $\mathrm{His}_{6}-\mathrm{-ОГ.}$

Разработанный в России материал включает: верхний слой, изолирующий от проникновения токсичных веществ в виде жидкости; средний сорбирующий и самодегазирующийся слой содержит фермент; нижний слой, выполненный из тканого или нетканого целлюлозосодержащего материала, предназначен для контакта с кожным покровом.

В виде верхнего слоя материал содержит полиуретановую или фторолефиновую мембранотканевую составляющую. В качестве дегазирующего элемента у разработанного материала - полипептид со свойствами органофосфатгидролазы ( $\mathrm{His}_{6}-\mathrm{-ФГ),} \mathrm{а} \mathrm{в} \mathrm{качестве}$ компонента, сорбирующего и удерживающего дегазирующий элемент в буфере, содержит сорбент - сшитый акрилат с проклейкой всех слоев материала связующим компонентом. Данный сорбент нетоксичен как при пероральном попадании в организм, при воздействии на кожные покровы и органы зрения человека и животных.

Применение полиуретановой или фторолефиновой мембранотканевой составляющей (полиамид-хлопчатобумажная ткань с полифторолефиновой или полиуретановой поверхностью, обладающая олеофобными 


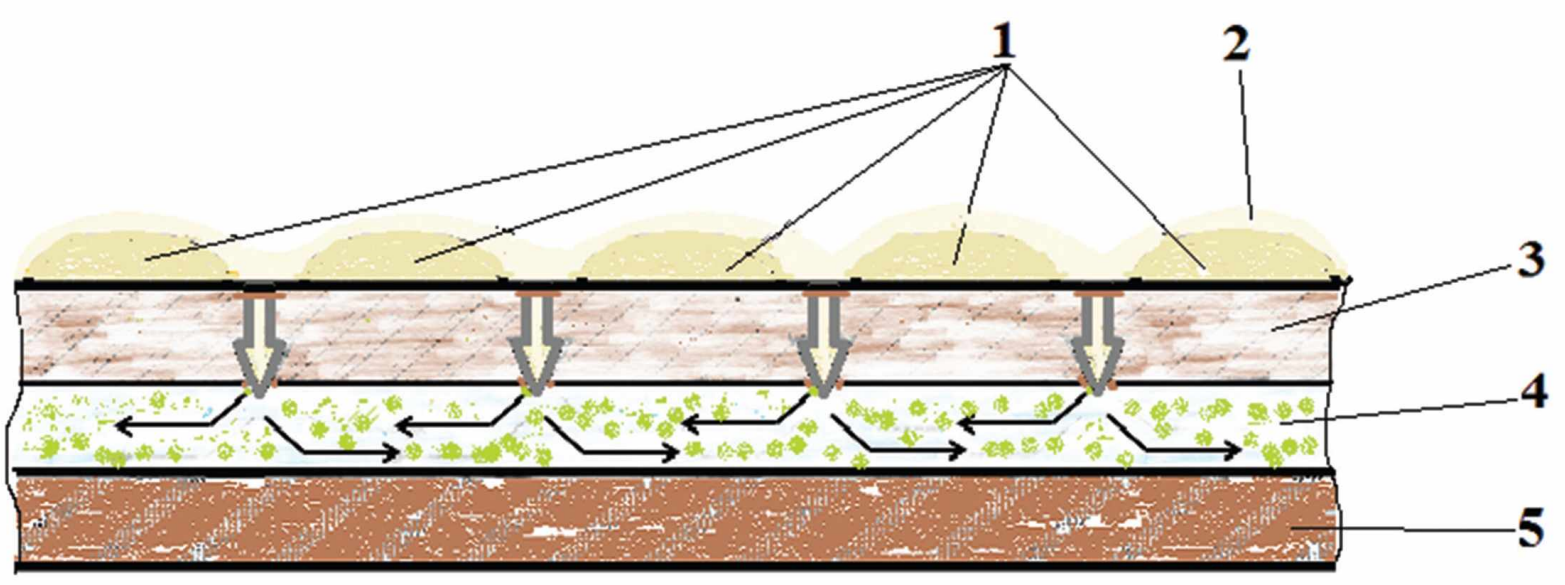

Рисунок 5 - Схема защитного материала на основе иммобилизованного фермента Нis -ОФГ (1 - капли ФОВ на поверхности материала; 2 - паровая фаза ФОВ в приповерхностном слое; 3 - верхний изолирующий слой; 4 - слой, содержащий иммобилизованный фермент Нis ${ }_{6} О Ф Г ; 5$ - нижний гигиенический слой)

свойствами) в защитном материале позволяет осуществлять защиту от жидкой фазы различных токсичных веществ, не пропуская ее к нижележащим слоям и кожным покровам. При этом обеспечивается равномерное распределение и дозировка подвода паровой фазы различных токсичных веществ к сорбирующему слою.

Использованная в данном материале физическая иммобилизация (сорбция) в объеме абсорбента раствора полипептида, обладающего свойствами органофосфатгидролазы, в нативной форме является новым, ранее неизвестным техническим решением при создании защитных материалов. Указанное выше сочетание всех основных компонентов фильтрующе-сорбирующего самодегазирующегося материала в соотношениях в составе материала ранее описано не было.

Испытания защитных свойств материала, в частности, проникновение отравляющих веществ через образцы, изучение кинетики разрушения фосфорорганических веществ в сорбционном слое, определение механизма и времени деструкции ОВ были проведены в 27 НЦ МО РФ по утвержденным методикам в соответствии с ГОСТ В 16797-76.

Проведенная экспериментальная проверка фильтрующе-сорбирующего самодегазирующегося материала показала, что олеофобная мембрана, представляющая верхний слой пакетов материалов, содержит само VX и дисульфид - один из первичных продуктов его распада, в то время как в среднем слое, который содержит иммобилизованный фермент His $-\mathrm{-OФ,} \mathrm{VX} \mathrm{и} \mathrm{дисульфид} \mathrm{отсутство-}$ вали. Однако в нем присутствовали продукты деструкции VX: МФК, ее кислый эфир и фос- форная кислота, что свидетельствовало о прошедшем процессе биокаталитического гидролиза как самого VX, так и продуктов его деструкции (эфиров МФК, МФК) под действием иммобилизованного фермента His -ОФГ. Обнаружение фосфорной кислоты, в свою очередь, указывает на возможное расщепление C-P связи в МФК $[41,42]$.

В таблице 1 представлены данные о степени конверсии субстратов (ФОВ и их структурных аналогов) с помощью иммобилизованной органофосфатгидролазы и ее модифицированной формы - генетически модифицированного фермента His -ОФГ, нанесенного на разные носители.

Другим известным вариантом материала, содержащего ОФГ и предназначенного для гидролиза ФОВ после удаления их с различных твердых поверхностей, в том числе кожи, является ткань, разработанная при использовании современного технологического оборудования, применяемого в текстильной промышленности для выпуска тканей, покрытых хитозановыми гелями, обеспечивающими материалу повышенную влагопоглощающую способность (Таблица 1) $[43,44]$.

Такая ткань перед ее применением может длительное время храниться без микробной контаминации во влажном состоянии в герметичных контейнерах, готовая к непосредственному применению.

Представляется целесообразным в дальнейшем проведение исследований пакетов защитных материалов, содержащих фермент органофосфатгидролазу $\mathrm{His}_{6}-\mathrm{O} Ф Г$ не только в нативной форме, но и в виде наноразмерных частиц полиэлектролитных комплексов фермента. 
И.В. Филимонов, А.А. Янковская, С.В. Кужелко и др.

Таблица 1 - Каталитические характеристики иммобилизованной ОФГ в реакциях гидролиза различных ФОВ и их структурных аналогов

\begin{tabular}{|c|c|c|c|c|}
\hline Тип иммобилизации & Носитель & Субстрат & $\begin{array}{c}\text { Степень } \\
\text { конверсии } \\
\text { субстрата, \% }\end{array}$ & $\begin{array}{l}\text { Ссылка на } \\
\text { литературу }\end{array}$ \\
\hline \multicolumn{5}{|c|}{ Препараты для технологии разложения ФОВ } \\
\hline $\begin{array}{l}\text { Ковалентная с помощью } \\
\text { глутарового альдегида }\end{array}$ & найлон & ДФФ & 20 & [45] \\
\hline Физическая адсорбция & тритил-агароза & ДФФ & 22,5 & [46] \\
\hline $\begin{array}{c}\text { Ковалентная с помощью } \\
\text { изоцианатпропилового спирта }\end{array}$ & $\begin{array}{l}\text { Силикагель, } \\
\text { полиуретан }\end{array}$ & ДФФ & $\begin{array}{l}95 \\
45\end{array}$ & [47] \\
\hline \multicolumn{5}{|c|}{ Препараты для защитных материалов } \\
\hline $\begin{array}{l}\text { Физическая } \\
\text { абсорбция }\end{array}$ & латексная краска & $\begin{array}{l}\text { Зоман, } \\
\text { ДФФ, } \\
\text { VX }\end{array}$ & $\begin{array}{l}62 \\
32 \\
45\end{array}$ & {$[48,49]$} \\
\hline $\begin{array}{l}\text { Ковалентная с помощью } \\
\text { глутарового альдегида }\end{array}$ & $\begin{array}{c}\text { хитозановый гель на } \\
\text { тканевой подложке }\end{array}$ & ДФФ & 100 & [43] \\
\hline $\begin{array}{l}\text { Физическая } \\
\text { абсорбция }\end{array}$ & $\begin{array}{l}\text { акрилатный гель на } \\
\text { тканевой подложке }\end{array}$ & $\begin{array}{l}\text { Зоман, } \\
\text { зарин, } \\
\text { VX }\end{array}$ & 100 & [41] \\
\hline
\end{tabular}

Иной подход к обеспечению безопасности в отношении ФОВ за счет создания защитных фермент-содержащих средств был продемонстрирован компанией Reactive Surfaces Ltd. (США) в виде биокаталитических латексных красок, имеющих сегодня торговую марку $\mathrm{OPD}_{\text {тох }}{ }^{\mathrm{TM}}$ (Таблица 1) $[48,49]$. Данная разработка подтверждает возможность использования ОФГ в качестве основного действующего компонента защитного материала, наносимого на какую-либо поверхность (транспорт, стены помещений, реакторы и др.).

Исследование эффективности гидролитического действия биоактивных красок в отношени И ФОВ позволило установить, что степень конверсии токсичных веществ не достигает $100 \%$, по-видимому, вследствие ограничения каталитической реакции по наличию в микроокружении фермента воды. В то же время показано, что смачивание поверхности, покрытой биоактивной краской, содержащей рекомбинантную ОФГ, позволяет активировать ферментативный катализ.

Таким образом, анализ современных достижений в химической энзимологии, биотехнологии и приведенные результаты исследований подтверждают перспективность применения стабилизированных форм фермента для разложения ФОВ в составе защитных материалов, а также отражают растущий к ним интерес.

\section{III Биокатализаторы для очистки окру-} жающей среды

При помощи биокатализаторов на основе ферментов и микроорганизмов-деструкторов можно проводить очистку почвы, воды и твердых поверхностей, загрязненных ФОС, в том числе ФОВ и токсичными продуктами их деструкции.

К настоящему времени выделено значительное число бактериальных ферментов и штаммов микроорганизмов-деструкторов, катализирующих гидролиз ФОС и в том числе ФОВ. Проведенная модификация активных центров ферментов позволила получить большое количество мутантов, отличающихся способностью к эффективному катализу деструкции ФОС и ФОВ.

Детоксикация различных ФОС в почве, воде и на различных твердых поверхностях с помощью биокаталитических систем довольно широко исследуется на протяжении последних десятилетий. Впервые бактериальные ферменты, катализирующие гидролиз фосфорорганических токсикантов с высокой скоростью и широкой специфичностью к субстрату, были выделены 1940-е гг.

Так, из образцов почв была выделена фосфотриэстераза (ФТЭ), накапливающаяся в клетках бактерии рода Flavobacterium [50]. Приблизительно в то же самое время из почвенной бактерии Pseudomonas diminuta был выделен фермент, гидролизующий параоксон [51]. По- 
Исследования в сфере перспективного использования химико-биологических и медицинских...

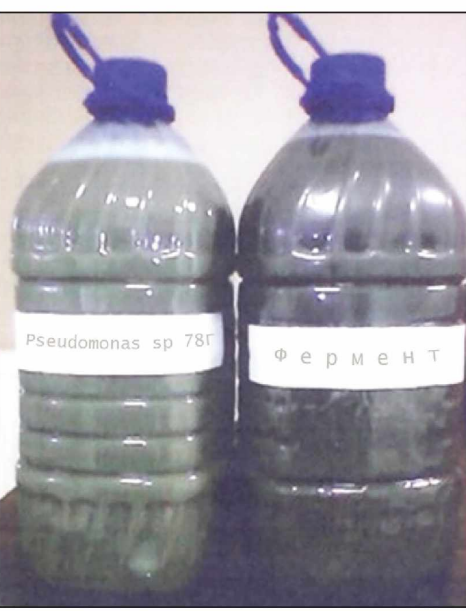

A

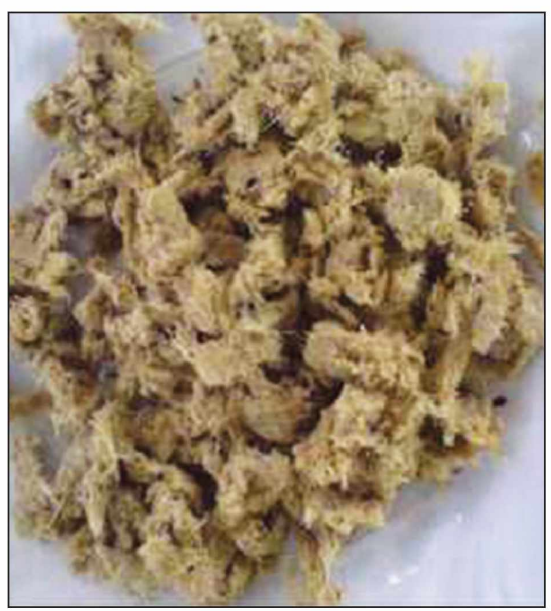

Б

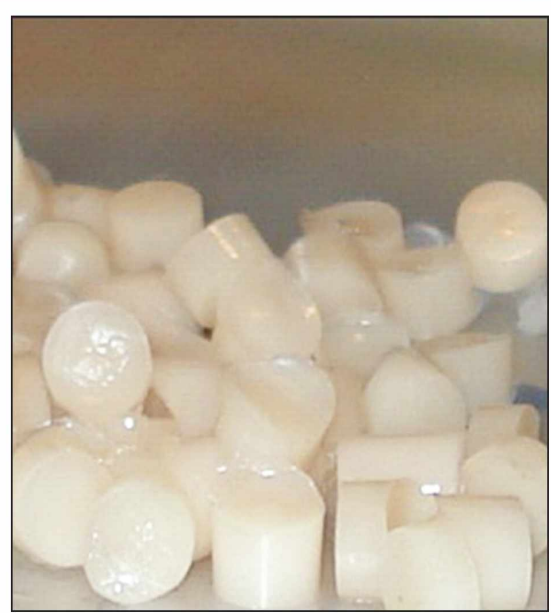

B

Рисунок 6 - Виды биопрепаратов на основе фермента Ніs6-ОФГ и клеток микроорганизмов-деструкторов Pseudomonas sp. 78Г для очистки почвы и воды, зараженных ФОС и продуктами их детоксикации (A - Биокатализатор на основе клеток Pseudomonas sp. 78Г; Б - Биокатализатор на основе фермента His -ОФГ, нанесенный на делигнифицированную пшеничную солому; В - Гранулы биокатализатора на основе клеток Pseudomonas sp. 78Г иммобилизованных в криогель поливинилового сnupma)

следовательности генов, кодирующих синтез обоих ферментов, оказались идентичны.

Ген из клеток бактерии рода Pseudomonas был клонирован в разных «хозяевах», включая клетки Escherichia coli [52]. Полученный при этом рекомбинантный фермент ФТЭ исследовался для выяснения его способности гидролизовать ФОВ с высокой скоростью, тогда как эти же самые ФОВ являются чрезвычайно мощными ингибиторами АХЭ.

Установлено, что мутантный фермент ФТЭ способен гидролизовать параоксон с огромной скоростью: $\mathrm{k}_{\text {cat }}=3,000 \mathrm{c}^{-1}$. Большая часть исследований оценки ФТЭ проводилась с производными параоксона, поскольку концентрация накапливающегося продукта нейтрализации (нитрофенолят-иона) относительно просто определяется спектрофотометрическим методом [53].

В качестве эффективных средств для очистки окружающей среды особый интерес представляют биокатализаторы на основе ферментов и микроорганизмов-деструкторов.

На рисунке 6 представлены разные виды биокатализаторов на основе фермента и микроорганизмов-деструкторов, которые использовались для очистки почвы и воды, содержащих ФОС и продукты их разложения.

В отличие от других методов обезвреживания токсичных веществ, использование биокатализаторов на основе ферментов и штаммов микроорганизмов-деструкторов выгодно отличается отсутствием вторичных отходов, высокой степенью деградации, возможностью полной ассимиляции продуктов $[50,51]$.
В качестве конечных продуктов при деградации ОВ и продуктов их детоксикации с помощью таких биокатализаторов образуются углекислый газ, метан, вода и неорганические соли $[52,53]$.

Исследования, проведенные отечественными и зарубежными учеными, показали, что, используя биотехнологические методы, можно достичь повышения уровня ремедиации почвы, восстановления воды и очистки поверхностей за счет полной деструкции (минерализации) продуктов детоксикации отравляющих веществ и попавших в них токсичных химикатов [54-72].

Публикации, касающиеся разложения отравляющих веществ в почве и водных растворах с участием микроорганизмов и ферментов, появились в научной литературе в 1990-х гг. [73-78].

Так, группа исследователей под руководством Chakrabatru и Camely получила фермент, способный разрушать химические связи в ОВ нервнопаралитического действия (зарин, зоман, табун). Авторами показано, что выделенный фермент - кислая ангидролаза - продуцируется микроорганизмом рода Altermonas и может быть использован для детоксикаци почвы и других природных сред [79].

Оказалось, что многие природные штаммы микроорганизмов содержат в своих клетках ферменты, способные катализировать гидролиз ингибиторов ацетилхолинэстеразы, включая ДФФ, зоман и другие ФОС.

Примером таких штаммов является штамм Tetrahymena thermophile, из клеток которого выделены четыре формы кислой ан- 
гидролазы. Фосфортриэстеразы, выделенные из штамма Pseudomonas diminuta, с высокой эффективностью проводят расщепление C-P связи в молекулах зарина и зомана [79], а фермент пропилфторфосфотаза, полученный из клеток Pseudomonas diminuta $M G$, осуществляет расщепление диизопропилфторфосфоната $[80,81]$.

Американский ученый De-Frank обнаружил несколько видов морских бактерий, способных продуцировать нетоксичные ферменты, которые разрушают ФОВ в условиях химического заражения местности [82].

Поскольку ферменты - это биологические катализаторы, то для обеззараживания загрязненных почвы, воды и твердых поверхностей требуется небольшое их количество. Важнейшим преимуществом такой ферментативной деструкции является совместимость ферментов с любыми биологическими системами, что обеспечивает экологическую безопасность процесса деструкции малых концентраций ОВ, продуктов их детоксикации и отходов.

Кроме этого, процесс биотрансформации ФОВ может проходить под действием не только ферментов, выделенных из клеток бактерий, но и под действием анаэробных и аэробных штаммов микроорганизмов или их ассоциаций, а также дрожжей и грибов [83-86]. Было показано, что анаэробное разложение под действием метаногенных микроорганизмов протекает при $\mathrm{pH}=4-10$ и температуре от 5 до $60^{\circ} \mathrm{C}$, в течение от нескольких суток до нескольких месяцев. Бионейтрализация ОВ и продуктов детоксикации делает процесс их уничтожения полностью необратимым.

По мнению ученых, микробиологическое разложение ФОВ, содержащих С-Р связь, в том числе О-изопропилового и О-пинаколилового эфиров метилфосфоновой кислоты, которые являются продуктами гидролиза зарина и зомана, осуществляется практически полностью путем непосредственного расщепления С-P связи с выделением метана штаммом Pseudomonas testosterone [87 - 89].

Известно, что продукт детоксикации ФОВ - метилфосфоновая кислота (МФК) стабильна в окружающей среде [90-95], так как она устойчива к гидролизу и термическому разложению. Это соединение было обнаружено спустя 10 лет после заражения сухой почвы на полигоне Дагуэй (США). Скорость разложения МФК в окружающей среде определяется процессами биодеструкции и прочностью связи C-P, испарение кислоты из воды невозможно, так как МФК в воде может диссоциировать [96-98].
Установлено, что чем сильнее молекулярное строение того или иного загрязнителя отклоняется от строения близких природных веществ, тем сложнее идет процесс его биологического разложения [99].

Способность микроорганизмов использовать фосфорорганические соединения с C-P связью в качестве единственного источника фосфора известна сравнительно давно. Впервые доказательство биологического расщепления С-Р связи было получено на примере E. coli, которая в качестве единственного источника фосфора использовала метилфосфоновую или этилфосфоновую кислоты [100].

Анализ работ по микробиологическому разрушению фосфонатов показал, что в природе существует большое количество микроорганизмов-деструкторов фосфонатов, относящихся к разным систематическим группам. Такие микроорганизмы были выделены как из загрязненных, так и из незагрязненных фосфонатами источников окружающей среды. Однако разлагать фосфонаты способны, скорее, только особые штаммы или определенные их ассоциации [101]. Это свидетельствует о более широком распространении фосфонат-разлагающих микроорганизмов, чем предполагалось paнее [84].

Отмечена способность к деградации у фотосинтетического организма Rhodobacter capsulatus, галофильных бактерий Chromohalobacter marismortui и термофильных бактерий Geobacillus caldoxylosilyticus.

Большинство бактерий, способных разрушать фосфонаты по С-P лиазному механизму, относятся к грамотрицательным бактериям, однако известны и представители грамположительных бактерий - Arthrobacter sp. GLP-1 и Bacillus megaterium, обладающие подобной способностью. У других грамположительных бактерий C-P лиазная активность не обнаруживалась. С-Р лиазную активность проявляют в основном отдельные представители классов Arthrobacteriaceae, Bacillaceae, Rhodobacteriaceae, Alcaligenaceae, Pseudomonadaceae, Enterobacteriaceae (Escherichia, Enterobacter, Klebsiella, Kluyvera) и Rhizobiaceae (Rhizobium, Agrobacterium).

Наименее изученными являются процессы микробиологического разложения иприта [бис(2-хлорэтил)сульфид]. С одной стороны, это вещество гидролизуется в присутствии воды с последовательным образованием иприт-хлоргидрина и тиодигликоля, а с другой - имеются примеры поражения людей остатками иприта через 50 лет после его попадания в почву [102]. Результатов непосредственного экспериментального изучения динамики изменения концентрации 
иприта в почвах в открытой литературе не описано. Возможно, что при недостатке воды в почвах иприт разлагается с образованием 1,2-бис(2-хлорэтилтио)этана и более высокомолекулярных аддуктов, а также 1,2-дихлорэтана и 1,4-дитиана.

Предполагают, что иприт достаточно долго сохраняется в почве в капсулированном виде в высокомолекулярных продуктах, что замедляет его растворение и разложение [103].

В литературе имеются данные, свидетельствующие, что в водных системах происходит полное разложение иприта под действием бактерий Pseudomonas testosterone и Pseudomonas putida, выделенных из донного ила Мексиканского залива и утилизирующих тиодигликоль [104].

Рассматривая возможность биодеструкции иприта в водных средах, нельзя не отметить тот факт, что иприт сам по себе плохо растворяется в воде. Кроме того, при контакте c водой он принимает шарообразную форму и его частицы образуют нерастворимую оболочку. Эти глобулы чрезвычайно устойчивы к воздействию факторов окружающей среды. Поэтому для деструкции иприта в водной среде используют системы органических растворителей в смеси с водой. В работе Milstein [105] показана возможность использования ферментов для разложения иприта с применением 17-ти различных органических растворителей и воды. Было отмечено, что присутствие воды необходимо для успешного процесса деструкции данного ОВ.

Известно, что иприт и органоарсениты необратимо воздействуют на молекулы биообъектов. Так, технический иприт и рецептура иприта реагируют с нуклеиновыми кислотами в организме с образованием мутаций. Это, в свою очередь, может ограничивать применение микроорганизмов для уничтожения иприта и органоарсенита. Применение же бактерий для разложения продуктов их нейтрализации является весьма эффективным.

Чрезвычайно сложной представляется очистка окружающей среды от мышьяка. Для снижения концентрации арсенитов в грунтовых водах до предельно допустимого уровня (50 мкг/мл) предлагается адсорбция их из водоносных пластов на мелкодисперсном алюминии [106]. Одновременно, как наиболее перспективный способ удаления мышьяка из почв, рассматривается абсорбция его биоокисляющими микроорганизмами при предварительной обработке почвы.

Технология сходна с технологиями, используемыми в процессе добычи металлов. При этом происходит концентрирование в клетках микроорганизмов содержащегося в почве мышьяка [107]. Исследования, проведенные с использованием лабораторного реактора непрерывного действия, показали, что бактерии Sulfolobus, окисляющие арсенопириты, обеспечивают полный переход содержащегося в почве мышьяка в раствор [108]. Выделенные из загрязненной мышьяком окружающей среды бактерии Pseudomonas putida оказались резистентны к его высоким концентрациям (до 10 г/л). Эти микроорганизмы разлагают метилированные производные мышьяка, что может быть использовано для биотехнологического восстановления почв.

Известно, что растения способны абсорбировать мышьяк и другие тяжелые металлы из почв и грунтов и тем самым очищать их. В патенте [109] предложен способ очистки почв, загрязненных продуктами природного и техногенного разложения токсичных веществ. Для очистки почв от тяжелых металлов используют сельскохозяйственные растения: сорго, суданская трава, подсолнечник.

При этом отмечается, что доступность тяжелых металлов растениям не постоянна. Она варьируется от одного вида растений к другому, зависит от почвенных и климатических условий. К почвенным факторам, значительно влияющим на доступность поглощения тяжелых металлов, относятся: механический состав, реакция (pH) почвы, содержание органического вещества, катионообменная способность и дренаж [110].

Для обеспечения экологической безопасности водных объектов, в которые сбрасываются сточные воды с химических объектов, содержащие «осколки» различной химической природы, необходима система доочистки стоков от загрязнителей до регламентируемых уровней.

Так, для очистки стоков, содержащих избыточное количество фосфора, необходимо предварительное проведение трансформации в легкодоступные для бактерий формы. Например, микроорганизмы Bacillus megaterium var. phosphaticum превращают труднодоступные формы фосфора в легкоусвояемые [111].

Биологическое окисление и восстановление фосфора имеет ряд особенностей. Фосфор, подобно азоту и сере, имеет ряд валентностей от $\mathrm{P}^{3-}$ в фосфористом водороде до $\mathrm{P}^{5+}$ в ортофосфорной кислоте. Но, в противоположность азоту и сере, почти не обращалось внимания на способность микробов переводить фосфор из одной степени окисления в другую.

Микроорганизмы в присутствии органического вещества способны в анаэробных условиях восстанавливать соли фосфорной 
кислоты вплоть до фосфористого водорода. Процесс, по-видимому, в биохимическом отношении аналогичен денитрификации [112].

Создание в очистных сооружениях чередования аэробных и анаэробных условий может привести к активации механизма клеточного накопления и стимулирования процессов денитрификации и абсорбции фосфатов.

Наблюдения за работой производственных очистных сооружений показали, что активный ил, выдержанный в анаэробных условиях, содержит двухвалентное железо в форме сульфида железа и фосфата закиси железа. При использовании такого ила в качестве биогенных добавок и источника $\mathrm{Fe}^{2+}$ в аэротенках развиваются бактерии Leptothrix, в метаболизм которых включается фосфат закиси железа. Он накапливается в пустых отмерших клетках бактерий в виде фосфата железа, который удаляется с избытком активного ила. В очищенной таким методом воде фосфор полностью отсутствует [113].

Аэробная биологическая очистка сточных вод ведет к минерализации значительной части окисляемых бактериями органических веществ, но обычно не способна устранить более $50 \%$ фосфорных соединений. Возникающие трудности связаны с нарушением оптимальных соотношений углерода, азота и фосфора в активном иле, при которых оптимизирован процесс микробной утилизации этих соединений. В связи с этим при очистке сточных вод от азота и фосфора используют широко распространенный способ применения культур микроводорослей.

Имеются сообщения об успешном использовании смешанных культур микроводорослей родов Chlorella и Scenedesmus для очистки сильно загрязненных стоков. При этом достигается очистка на $90 \%$ по азоту и фосфору $[114,115]$.

В работе [116] установлено, что зеленые водоросли извлекают от 50 до $96 \%$ фосфора при концентрации 10-20 мг/л в течение 2-3 суток.

Проведенный анализ литературных данных по очистке сточных вод от соединений фосфора показал, что перспективным методом является комбинированный метод, сочетающий химическое осаждение с микробиологической очисткой [117-123]. Осаждение фосфатов в этом методе осуществляется путем добавления водорастворимой соли алюминия, кальция, железа или солями редкоземельных элементов (хлорид или сульфат лантана). Отделение осажденных фосфатов можно облегчить применением флокулянта, водорастворимого органического полиэлектролита, например, частично гидролизованного полиалкиламина $[124,125]$.
Из литературы известны комбинированные физико-биологические методы удаления фосфора из сточных вод, примером такого метода является использование мембранного разделителя, через который пропускаются сточные воды после обработки их бактериями, потребляющими фосфор [126].

Необходимо отметить, что после применения таких комбинированных методов очистки, даже при минимальном содержании в них контролируемых загрязнителей, необходимо проведение токсикологического анализа очищенных сточных вод в связи с тем, что сложные органические вещества при разложении способны соединяться с различными продуктами метаболизма микроорганизмов с образованием токсичных продуктов биосинтеза.

Токсикологическую оценку качества обезвреживаемых стоков рекомендуется проводить биотестированием с использованием живых водных организмов [127-130].

Биотестирование дает гарантированную оценку безопасности очищенных сточных вод и позволяет выбрать такие способы очистки, которые обеспечивают не только достаточное разложение загрязнений, но и полную детоксикацию сточных вод. Это особо важно при глубокой биологической очистке воды, содержащей продукты деструкции отравляющих веществ.

Анализ исследований, проведенных на протяжении последних десятилетий, показал, что российскими учеными в этот период были разработаны биотехнологические методы, созданы, наработаны и экспериментально апробированы нейтрализующие средства (биокатализаторы на основе ферментов и штаммов микроорганизмов-деструкторов), обладающие повышенной способностью к разложению отравляющих веществ и продуктов их детоксикации в процессе очистки почв и вод. Определены основные технологические операции и стадии биоремедиации почвы и очистки воды в реакторах ex situ и непосредственно в условиях окружающей среды in situ. Разработана «дорожная карта» биотехнологической экологически безопасной санации почвы и очистки воды in situ [131-134].

Полученные биокатализаторы на основе штаммов микроорганизмов-деструкторов были испытаны при рекультивации почвы объекта по уничтожению химического оружия «Марадыковский» [135-137]. Биокатализаторы на основе фермента His-ОФГ и консорциумов микроорганизмов-деструкторов апробированы в лабораторных условиях для очистки разных видов почв и вод, загрязненных ФОС, ФОВ и продуктами их деструкции [72, 74, 76, 138]. 
Интересным направлением исследований оказалось создание пенных покрытий, содержащих ферменты (ФПП) для очистки твердых поверхностей, загрязненных токсичными химикатами.

Идея использования ферментов, в частности ОФГ, в составе пенных композиций принадлежит американским исследователям, которые в конце 1990-х гг. впервые апробировали использование высокоочищенного фермента ОФГ, не имеющего в своей структуре полигистидиновой последовательности, для введения в «Пенные системы» [139]. В частности, они смешивали ОФГ со «стандартным» пенообразователем для пожаротушения «First Defense» (4 \%-ный рабочий раствор), подвергали полученную рецептуру механическому вспениванию в течение 30-40 сек. и полученной пеной обрабатывали поверхность, загрязненную ФOC.

Кратность пены составляла 9. Остаточная ферментативная активность, определенная в жидкой фазе, после оседания пены составляла $10 \%$ от изначально внесенной. Тем не менее, такой активности было достаточно, чтобы в течение 1 ч полностью гидролизовать пестицид параоксон, нанесенный в концентрации 0,72 г/M ${ }^{2}$ и распределенный по поверхности в виде слоя пены высотой 1,2 см, который был сформирован из раствора ОФГ $\left(3,4 \mathrm{M \Gamma}_{\text {белка }} / \pi\right)$ с исходной активностью 8,9 Ед./мл. Увеличение в проводимых экспериментах концентрации загрязняющего вещества в 5,8 раз (до 4,2 $\boldsymbol{\Gamma}_{\text {параоксона }} / \mathbf{M}^{2}$ ) потребовало увеличения ферментативной активности, присутствовавшей в составе пенной рецептуры, в 4,6 раза, но при этом степень разложения параоксона за 1 ч составила только $70 \%$. Следовательно, для детоксикации сильного загрязнения ФОС требуется увеличение ферментативной активности и/или слоя пенного покрытия. Как следствие, можно ожидать, что длительность экспонирования пены может быть снижена до 30 мин, так как 90-95 \% загрязнителя ферментативно гидролизуется в течение этого времени.

Необходимо отметить, что в России также были проведены исследования по созданию пенного покрытия, но на основе фермента His -ОФГ [140]. Была использована стабильная форма фермента, полученная путем иммобилизации. Исследования показали, что увеличение остаточной активности стабилизированного фермента Нis 6 -ОГ в 3 раза по сравнению с ОФГ в соответствующее число раз увеличивало предельную концентрацию загрязнителя, гидролизуемого за тот же период времени. Вкупе с увеличенной исходной активностью и расширенной субстратной специфичностью, которой обладает $\mathrm{His}_{6}-\mathrm{-ОГ} \mathrm{в} \mathrm{сравнении} \mathrm{с} \mathrm{ОФГ,}$ это приводит к существенному повышению суммарного положительного эффекта от действия такой пенной рецептуры.

В созданное фермент-содержащее пенное покрытие были включены:

- фермент His-ОФГ как наиболее активный из всех известных ферментов, гидролизующих различные ФОС;

- карбонатный водный буфер как основа для создания среды, обеспечивающей поддержание фермента в максимально активной форме;

- пенообразующий компонент в концентрации, необходимой для получения устойчивой пены в течение определенного времени, в соответствии с рекомендациями его производителей.

По мнению авторов, ФПП может быть использовано для дегазации различных поверхностей, загрязненных ФОС. ФПП обеспечивает гидролиз ФОС при нанесении на ВВСТ, почву, вертикальные твердые поверхности, а также на обмундирование личного состава в течение 30-60 мин. Может применяться при положительных температурах окружающего воздуха $\left(8-40^{\circ} \mathrm{C}\right)$ вне зависимости от уровня влажности и атмосферного давления.

Пенное покрытие может наноситься на обрабатываемую твердую поверхность слоем в 1-5 см (в зависимости от количества загрязняющих ФОС). Изготавливается непосредственно или незадолго перед использованием. Оно может быть также использовано в случае аварийных развалов твердых ФОС и розливов жидких ФОС на различных поверхностях, в том числе ВВСТ. Рабочий раствор пенного покрытия не токсичен для человека и животных, поэтому в исключительных случаях может быть применен для удаления ФОС с кожных покровов.

На рисунке 7 представлены образцы кафельной плитки с остатками старой штукатурки, которые были загрязнены параоксоном и после обработаны пенным покрытием, полученным при помощи миксерной технологии. Половина поверхности была обработана пеной без фермента, а вторая половина - добавлением фермента $\mathrm{His}_{6}-\mathrm{O} Ф$.

Через 5-10 мин с помощью шпателя были освобождены некоторые участки твердой поверхности от пены. В случае использования пены с ферментом His-ОФГ на открытых поверхностях кафельной плитки наблюдали желтую окраску пены, которую давал продукт гидролиза параоксона - П-нитрофенол. Такая окраска отсутствовала в случае использования обычной пены без фермента. 
I.V. Filimonov, A.A. Yankovskaya, S.V. Kuzhelko et al.
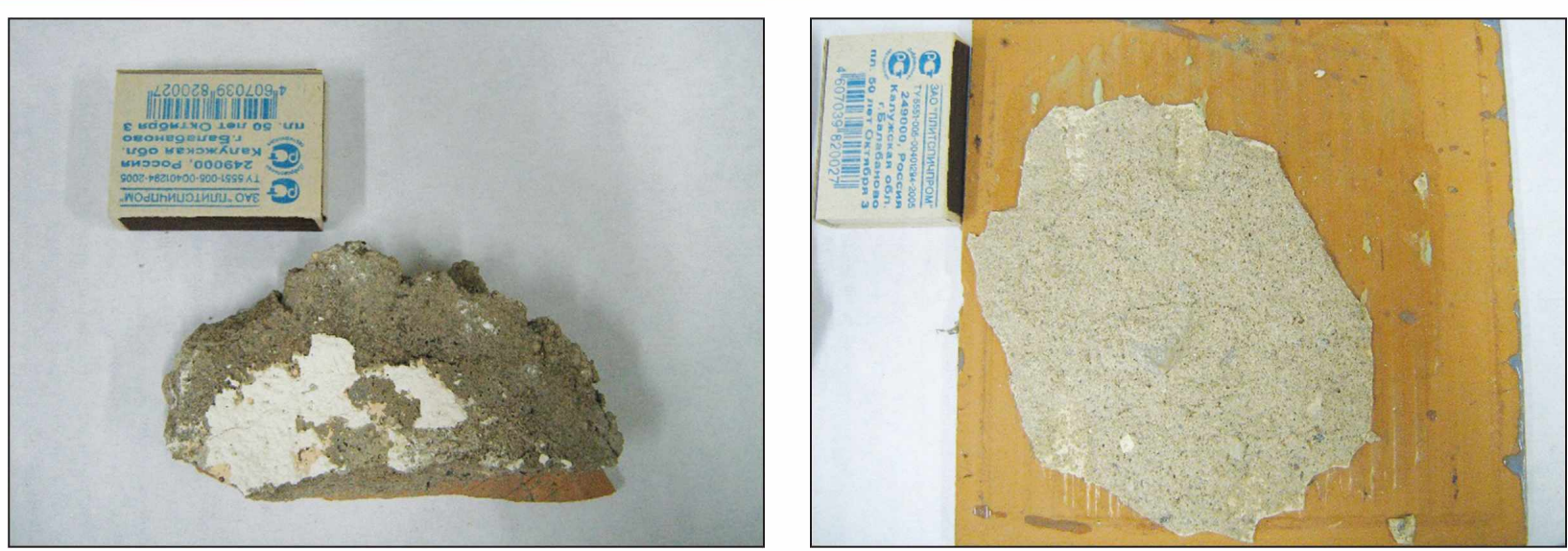

A
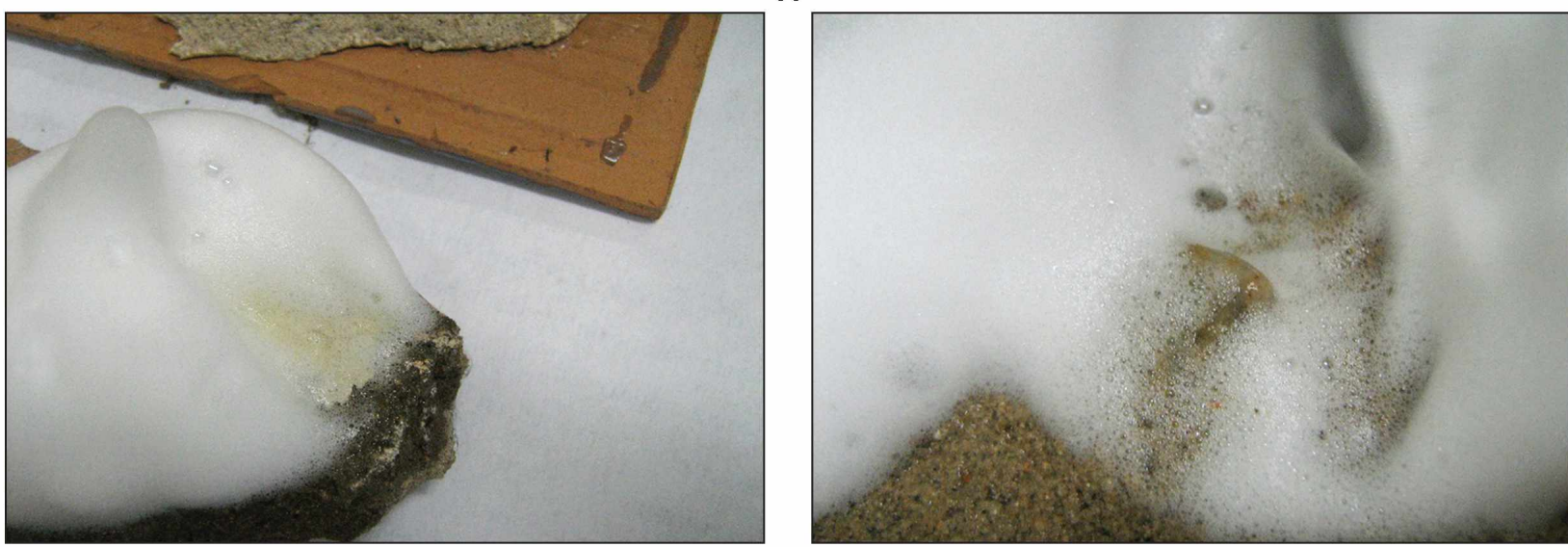

Б

Рисунок 7 - Обработка твердой поверхности фермент содержащим пенным покрытием (А - Образцы штукатурки перед обработкой; Б - Образцы штукатурки после загрязнения параоксо-

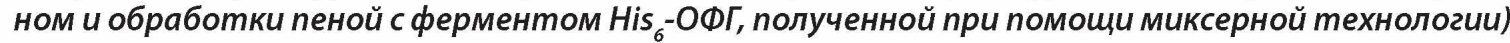

Такой же эффект наблюдали при обработке поверхности влажного песка при по-

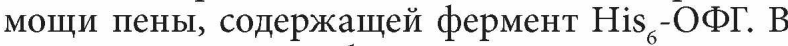
качестве контроля были использованы: пена, не содержащая фермент, песок, влажный песок, само вещество параоксон.

Образцы пены получали также миксерной технологией. Обнаружение параоксона проводили газохроматографическим методом. В образцах, содержащих влажный песок, в который был добавлен параоксон и обработанный пеной с ферментом His 6 -ОФГ, после 3-4 ч инкубации, полностью отсутствовало вещество параоксон. Следовательно, фермент, содержащийся в пене, осуществил полную деструкцию параоксона. Причем как и в случае с дегазацией на поверхности плитки (рисунок 7), наблюдали желтую окраску пены, которую дает п-нитрофенол. Такая окраска отсутствовала в контрольных образцах.

Таким образом, проведенный анализ литературных данных показал, что для очистки загрязненных токсичными вещест- вами почвы, воды и твердых поверхностей могут быть использованы ферменты, отдельные штаммы микроорганизмовдеструкторов и различные их консорциумы как в иммобилизованном виде, так и их суспензии.

Механизмы и схемы проведения биологической деградации экотоксикантов и продуктов их деструкции в водных растворах, почве и на твердых поверхностях различны для разных штаммов микроорганизмов-деструкторов, их консорциумов и ферментов. Поэтому при разработке биотехнологий по очистке необходимо учитывать активность фермента, видовое происхождение используемого в технологии микроорганизма или состав консорциума, их биодеградирующие свойства, особенности поведения в сообществе с различными природными штаммами, способность к изменчивости в условиях неоднородности субстрата, а также характеристики почвы воды и твердых поверхностей и факторы, влияющие на механизм и скорость биодеградации. 
IV Биопрепараты на основе ферментов и микроорганизмов-деструкторов для утилизащии реакционных масс, полученных путем химической детоксикации отравляющих веществ

Для утилизации реакционных масс (РM), образовавшихся после промышленного уничтожения (химической детоксикации) ФОВ, одним из наиболее привлекательных представляется биотехнологический подход, основанный на применении препаратов на основе ферментов и микроорганизмов-деструкторов.

Подсчитано, что количество образовавшихся РМ после уничтожения химического оружия в России в пять раз превосходит количество нейтрализованных отравляющих веществ. Основная часть этих РМ герметично затарена в металлические емкости и складирована в специальные подземные обвалованные железобетонные бункеры-хранилища до времени дальнейшей и окончательной их переработки.

Согласно принятым в России технологиям химического уничтожения ФОВ, в получаемых РМ остается часть неразложившихся нейротоксичных ФОВ [141, 142]. Поэтому дальнейшее обезвреживание образующихся РМ является крайне важной задачей, поскольку конечный состав РМ должен соответствовать нормативам токсикологической и экологической безопасности и быть безопасным для окружающей среды, а это означает, что необходимо провести разложение фосфонатов, как наиболее токсичных компонентов PM, и переработать РМ до безопасных продуктов деструкции [143].

Кроме того, МФК, которая является продуктом разложения диизобутилового и изобутилового эфиров МФК (продуктов детоксикации вещества типа VX), входящая в состав PM, также должна быть подвержена деструкции согласно Конвенции по запрещению и уничтожению химического оружия, как прекурсор ФОВ [144].

По нашему мнению, для разложения фосфорорганических компонентов РМ, полученных после уничтожения вещества типа VX, зарина и зомана, наиболее эффективными являются биокаталитические способы, поскольку они предполагают проведение биодеградации компонентов РМ в экологически безопасных условиях (без применения сильных химических окислителей и концентрированных щелочных растворов), а также в технологическом плане не требуют применения высоких температур, повышенного давления и использования оборудования, изготовленного из дорогих коррозионностойких материалов [145, 146]. При этом существует небольшой набор биологических катализаторов, которые могут быть вовлечены в схему разложения компонентов РМ, и самым эффективным способом использования может быть их комбинированное применение, позволяющее последовательно осуществлять процесс деградации образующихся продуктов детоксикации ФОВ $[5,6,9,14,76,130,138,145,146]$.

Анализ зарубежной литературы показал, что разработки относительно применения биокатализаторов на основе ферментов для целей уничтожения ФОВ касаются исключительно разложения чистых отравляющих веществ ферментами разной степени очистки [147-152]. Открытая информация об использовании ферментного гидролиза ФОС в составе сложных смесей - таких, какими являются РМ, получаемые по российской технологии уничтожения ФОВ, отсутствует [146].

В 2006-2007 гг. большой группой исследователей из ряда стран в рамках гранта HATO (Project Groop 31, «Некоррозионные, биотехнологические методы деконтаминации химических агентов») был разработан способ, согласно которому реакционные массы подвергали интенсивному окислению под действием $30 \%$ раствора перекиси водорода $\left(\mathrm{H}_{2} \mathrm{O}_{2}\right)$ и УФ-излучением. Затем для разложения образовавшейся при этом МФК растворы обрабатывали иммобилизованным биокатализатором, представляющим собой искусственный микробный консорциум, в который входили бактериальные культуры различных штаммов (Methylobacterium radiotolerans штамм GB21, Agrobacterium numefaciens штамм GB2GA, Klebsiella oxytoca штаммы GB2CS и GB272, Aureobactrium sp. штаммы GB2, GB23, GB272 и GB292) [153 - 157]. Адсорбционную иммобилизацию клеток консорциума осуществляли на гранулах из вспененного полиуретана с введенными в него частичками активированного угля. Перед применением иммобилизованных клеток для биоразложения фосфорорганических компонентов проводили их адаптацию к токсичным субстратам путем введения 5 мМ изопропилового эфира МФК.

Под действием внутриклеточных ферментов искусственного микробного консорциума МФК разлагалась, образующийся фосфат клетки микроорганизмов усваивали в качестве источника фосфора. Для поддержания жизнедеятельности микроорганизмов процесс проводили при дополнительном введении в РМ источника углерода (глюкоза и др.). Далее оставшуюся после обработки РМ иммобилизованными клетками неразложившуюся МФК осаждали из растворов хлоридом железа (III). Образующиеся стоки выпаривали и сушили.

Этот способ обеспечивал $99 \%$ разложение фосфорорганических компонентов. Общая длительность процесса занимала 

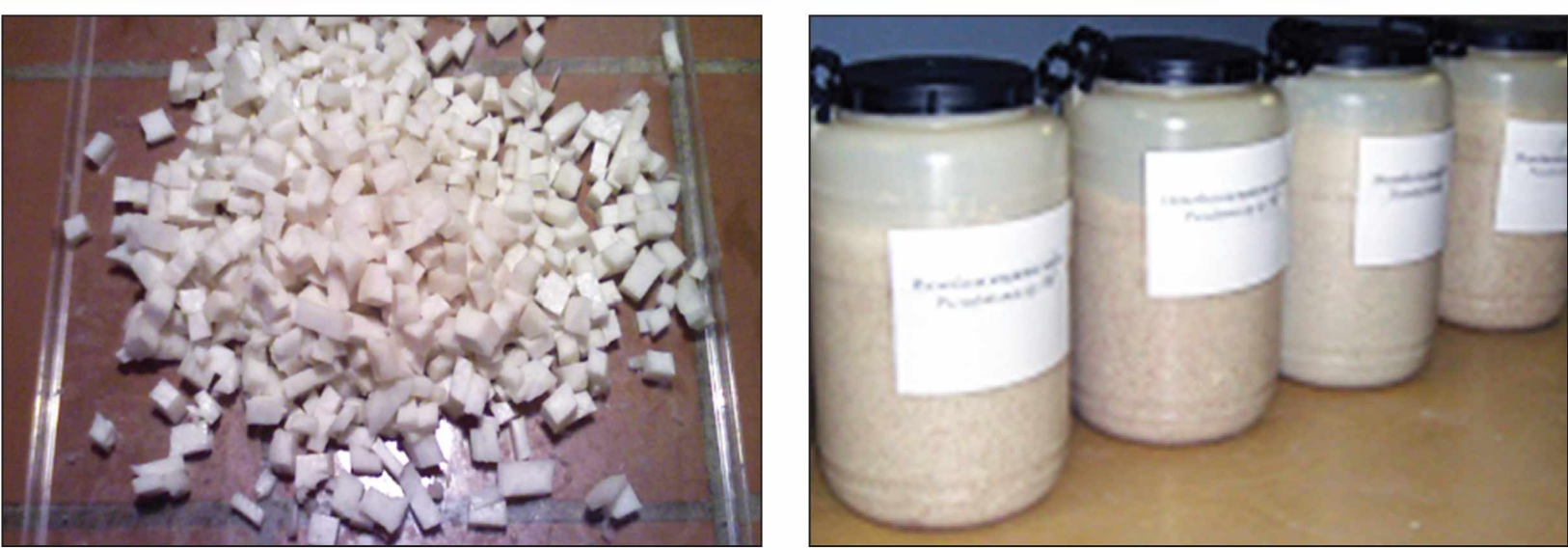

Рисунок 8 - Внешний вид биокатализатора на основе иммобилизованных клеток Pseudomonas sp. $78 \Gamma$., использованного на пилотной установке с целью обработки реакционных масс, полученных после уничтожения ФОВ

20 суток. Сухие остатки подлежали захоронению на специальных полигонах.

В России разработке эффективного способа детоксикации вещества типа VX и перевода токсичных химикатов в реакционные массы при воздействии на них рецептурой РД-4М было посвящено комплексное исследование, проведенное в 2007-2008 гг. [72, 138, 145, 146,158 - 160].

На рисунке 8 представлены препараты, полученные и использованные для биообработки РM вещества типа VX $[159,160]$.

В работах $[145,132]$ предложена технологическая схема реализации способа биоразложения РМ, которая представлена на рисунке 9.

На первой стадии проводится обработка с использованием фермента $\mathrm{His}_{6}-\mathrm{O} Ф$, который катализирует процесс полного разложения ФОВ и эфиров МФК.

На второй стадии продукты ферментативного гидролиза ФОВ (МФК и остаточное количество ее эфиров) разлагаются под действием биокатализатора на основе иммобилизованных клеток-деструкторов культуры Pseudomonas sp. 78Г, способной разрушать продукты детоксикации ФОВ, одновременно приводя к разрыву в алкилфосфонатах как С-O-P, так и С-P связи. Процесс проходит в минеральной среде, содержащей 0,5 \% глюкозы. Ферментный препарат, присутствующий в среде при подаче РМ, обработанных His $_{6}-О Ф Г$, в реакторе с иммобилизованными клетками микроорганизмов играл роль источника азота, необходимого клеткам для роста и утилизации фосфата, являющегося конечным продуктом разложения всех ФОС в составе РМ.

На третьей стадии в реакторе в культуральной жидкости, полученной при действии иммобилизованных клеток, за счет активного аэробного ила происходит снижение уровня химического потреб- ления кислорода (ХПК), формирующегося в результате накапливания клеточных метаболитов.

Состав сточных вод, обработанных аэробным активным илом после комплексного биоразложения ФОВ в составе РМ под действием фермента His 6 -ОФГ и биокатализатора в виде иммобилизованных клеток Pseudomonas sp. 78Г представлен в таблице 2.

Как видно из приведенных данных, при реализации российского технологического проекта по обезвреживанию РМ вещества типа VX были получены сточные воды, практически полностью удовлетворяющие требованиям, предъявляемым к канализационным стокам по химическому составу. Их экологическая безопасность была подтверждена тестами на экотоксичность, проведенными по установленным в России методикам [161].

Следовательно, сточные воды после биологической очистки становятся безвредными для основных трофических групп пресноводных гидробионтов, а полученные конечные продукты обладают минимальной токсичностью и экологической нагрузкой на окружающую среду.

Дополнительные экспериментальные исследования позволили оптимизировать условия реализации отдельных стадий общего процесса комплексной деструкции реакционных масс, получаемых при детоксикации вещества типа VX. В частности, стадии обработки РМ ферментным препаратом, стадии обработки иммобилизованными клетками-деструкторами культуры Pseudomonas sp. 78Г после воздействия ферментом и последующей стадии обработки культуральной жидкости активным аэробным илом $[138,158-160]$.

Предложенная технологическая схема имеет ряд преимуществ перед использованием бактериального консорциума в аналогичной схеме, разработанной в США [153-157]. 
В рамках российского технологического проекта по обезвреживанию РM вещества типа VX на всех стадиях его реализации использовались биологические катализаторы, осуществляющие дегазацию фосфорорганических компонентов в мягких условиях, что обеспечивает более безопасные условия работы для обслуживающего персонала и экологическую безопасность процесса в целом.

Показано, что модифиц и рованный фермент $\mathrm{His}_{6}-\mathrm{О} Г$ способен катализировать гидролиз вещества типа VX в широком интервале концентраций вплоть до 2,5 г/л в отсутствии субстратного ингибирования [158, 159].

Биокатализатор на основе клеток индивидуальной бактериальной культуры Pseudomonas sp. 78Г, иммобилизованных в криогель поливинилового спирта, способен обеспечить высокую скорость разложения токсичных субстратов на протяжении длительного времени: обеспечивает $100 \%$ разложение МФК при концентрациях 200 и 300 мг/л за 28 и 40 ч соответственно [160]. Этот катализатор также может эффективно осуществлять биоде-

градацию моноэфира МФК при очень высокой его концентрации (1 г/л), обеспечивая $50 \%$ его разложение за 48 ч; его эффективность в 4 раза выше, по сравнении с иммобилизованным бактериальным консорциумом, используемым в аналогичной технологии разложения МФК в СШІА.

Разработанная в России схема биоразложения фосфорорганических компонентов РМ

І стадия

III стадия
Водные растворы, содержащие

остаточные количества отравляющих веществ,

реакционные массы и продукты их деструкции

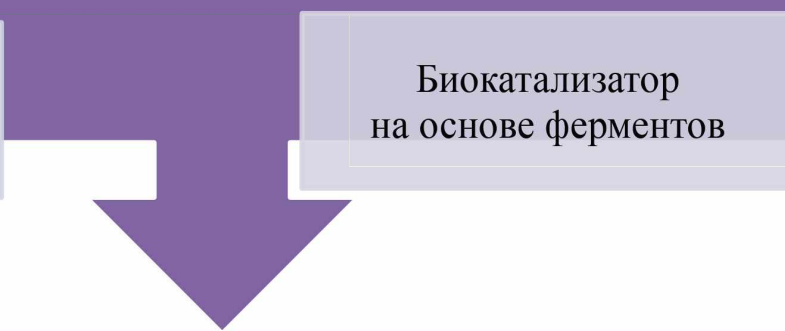

Водные растворы, содержащие

реакционные массы и продукты

деструкции отравляющих веществ

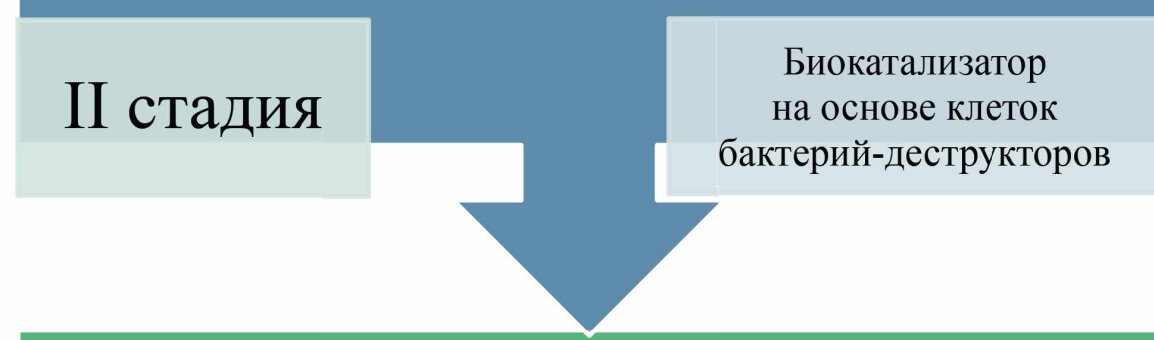

Водные растворы, содержащие

остаточные малые количества реакционных масс и

продуктов деструкции отравляющих веществ

Биокатализатор на основе активного ила с добавлением специфических штаммов

\section{Сточные воды после биообработки}

Рисунок 9 - Принципиальная технологическая схема реализации способа биоразложения реакционных масс вещества типа VX

носит универсальный характер и может быть применена для обработки РМ, полученных при уничтожении вещества типа VX, зарина и зомана различными химическими методами. При реализации данной схемы не образуются отходы, подлежащие захоронению в закрытых могильниках. Следовательно, данная схема может быть успешно использована для постепенного, поэтапного уничтожения складированных РМ. 
I.V. Filimonov, A.A. Yankovskaya, S.V. Kuzhelko et al.

Таблица 2 - Состав сточных вод, обработанных аэробным активным илом после комплексного биоразложения ФОС в составе РМ под действием фермента Ніs - -ОГ и биокатализатора в виде иммобилизованных клеток Pseudomonas sp. 78Г [138]

\begin{tabular}{|c|c|c|}
\hline Контролируемый параметр & $\begin{array}{c}\text { ПДК для канализационного } \\
\text { стока, мг/л }\end{array}$ & $\begin{array}{c}\text { Обнаруженная } \\
\text { концентрация, мг/л }\end{array}$ \\
\hline Азот (аммонийный) & 20,0 & $38 \pm 2$ \\
\hline Азот (нитрат) & 10,2 & $3,9 \pm 0,3$ \\
\hline Азот (нитрит) & 1,0 & $31 \pm 3$ \\
\hline Сульфаты & 500 & $30 \pm 1$ \\
\hline Хлориды & 350 & $2,5 \pm 0,4$ \\
\hline Фосфаты & 1,14 & $<0,1$ \\
\hline Метилфосфоновая кислота (МФК) & - & $<0,1$ \\
\hline Изобутиловый эфир МФК & - & $460 \pm 9$ \\
\hline Химическое потребление кислорода (ХпК) & 500 & $<20$ \\
\hline Экотоксичность, определяемая сиспользованием & $\leq 20$ & \\
\hline клеток светящихся бактерий & & \\
\hline
\end{tabular}

Направления исследований перспективного использования биопрепаратов в интересах создания изделий военного назначения различного типа

Анализ отечественных и зарубежных публикаций показал, что наиболее перспективными направлениями исследований, представляющими интерес для использования в области нанобиотехнологий при создании изделий военного назначения различного типа, являются:

\section{1 Ферментные антидоты}

Создание нового поколения лечебно-профилактических средств на основе наноразмерных ферментных препаратов, обладающих антитоксическим действием, которые могут быть использованы при отравлениях фосфорорганическими соединениями, в том числе фосфорорганическими отравляющими веществами.

2 Ферменты в составе самодегазирующихся материалов в качестве компонентов средств защиты

Создание самодегазирующихся средств индивидуальной защиты с использованием наноразмерных ферментных препаратов, гидролизующих фосфорорганические соединения, в том числе фосфорорганические отравляющие вещества и токсичные продукты их деструкции.

\section{3 Биокатализаторы для очистки окружа-} ющей среды

Разработка технологий очистки почвы, воды и поверхностей, загрязненных фосфорорганическими соединениями, в том числе фосфорорганическими отравляющими веществами и продуктами их детоксикации, при помощи биокатализаторов на основе ферментов и микроорганизмов-деструкторов.

4 Биопрепараты на основе ферментов и микроорганизмов-деструкторов для утилизации реакщионных масс отравляющих веществ

Создание биокаталитических препаратов на основе ферментов и микроорганизмовдеструкторов для утилизации реакционных масс, образовавшихся после промышленного уничтожения (химической детоксикации) отравляющих веществ.

\section{Заключение}

Проведенный анализ и обобщение результатов исследований и патентов отечественных и зарубежных ученых за последние три десятилетия по изучению ферментов (в нативном состоянии или в виде химически стабилизированных наноразмерных частиц ферментных биокатализаторов), микроорганизмов-деструкторов и их применению в области биологических технологий (в том числе и нанотехнологий), позволяет сделать выводы о 
перспективности использования для решения ключевых проблем в области защиты от ФОС, включая ФОВ, для гидролиза реакционных масс, полученных в процессе уничтожения OB, совершенствования средств защиты человека и окружающей среды, а также создания нового поколения антидотов.

Достоинства биотехнологий, основанных на использовании биокатализаторов, а именно: большая скорость процесса биохимического разложения; высокая степень деградации загрязнителей; избирательность по отношению к субстратам; возможность проведения деструкции до желаемых конечных продуктов; экономичность, находят широкое применение во многих странах мира в программах по охране окружающей среды, безопасной нейтрализации загрязнений, созданию современных средств индивидуальной и коллективной защиты, созданию антидотных препаратов.

Анализ показал, что российскими и зарубежными специалистами разработана совершенно новая биокаталитическая технология для защиты против отравлений ФОС in vivo, основанная на использовании ферментных наночастиц, которые могут быть применены в качестве профилактического и терапевтического средства. Ферментные антидоты могут иметь огромное значение для ликвидации и предотвращения интоксикации людей и животных ФОВ, на что не способен сейчас ни один известный в мире препарат.

Разработанные биокаталитические технологии на основе фермента $\mathrm{His}_{6}$-ОФГ отличаются простотой исполнения и экологической безопасностью, а получаемые биокатализаторы высокой активностью по отношению к широкому спектру ФОС. Полученные результаты могут быть основой для создания совершенно нового поколения средств индивидуальной и коллективной защиты войск и населения при ведении боевых действий, совершении террористических актов и в условиях техногенных аварий, а также средств специальной обработки средств защиты и ВBCT.

Предложенные биотехнологические методы очистки почвы, воды и твердых поверхностей, выгодно отличающиеся от других методов (химических, физических, механических) отсутствием вторичных отходов, высокой степенью деструкции малых концентраций OB, возможностью полной ассимиляции продуктов детоксикации ОВ и, следовательно, экологической чистотой процесса, позволяют осуществить комплекс мероприятий по нейтрализации химических угроз, предупреждению и минимизации рисков негативного воздействия химических факторов, повышению защищенности населения и окружающей среды при выведении из эксплуатации химически опасных объектов и проведении очистки территорий, загрязненных в результате их деятельности.

Наиболее перспективными направлениями исследований в области использования нанобиотехнологий при создании изделий военного назначения являются:

- ферментные антидоты;

- ферменты в составе самодегазирующихся материалов в качестве компонентов средств защиты;

- биокатализаторы для очистки окружающей среды;

- биопрепараты на основе ферментов и микроорганизмов-деструкторов для утилизации реакционных масс, полученных путем химической детоксикации отравляющих веществ.

\section{Информаиия о конфликте интересов}

Авторы заявляют, что исследования проводились при отсутствии любых коммерческих или финансовых отношений, которые могли бы быть истолкованы как потенциальный конфликт интересов.

\section{Сведения о рецензировании}

Статья прошла открытое рецензирование двумя рецензентами, специалистами в данной области. Рецензии находятся в редакции журнала.

Список источников

1. Уайт А., Хендлер Ф., Смит Э. и др. Основы биохимии. М.: 1981.

2. Варфоломеев С.Д. Биокинетика. М.: 1999

3. Физическая химия биопроцессов / Под ред. Варфоломеева С.Д. М.: 2014.

4. Молекулярный полиморфизм человека (в двух томах) / Под ред. Варфоломеева С.Д. М.: 2007.

$$
\text { 5. Ефременко E.H., Сергеева B.C. }
$$
Органофосфатгидролаза-фермент, катализирующий деградацию фосфорсодержащих отравляющих веществ и пестицидов // Известия АН. Серия: Химия. 2001. № 10. С. 1743-1749.

6. Ефременко Е.Н., Лягин И.В., Завьялов В.В. 
и др. Ферменты в технологии уничтожения фосфорорганических отравляющих веществ // Журнал российского химического общества им. Д.И. Менделеева. 2007. Т. LI, № 2. С. 24-29.

7. Efremenko E., Votchitseva Y., Plieva F. et al. Purification of His-organophosphate hydrolase using monolithic supermacroporous polyacrylamide cryogels developed for immobilized metal affinity chromatography // Appl. Microbiol. Biotech. 2006. V. 70, № 5. P. 558-563.

8. Efremenko E., Lyagin I., Gudkov D. et al. Immobilized biocatalysts for detoxification of neurotoxic organophosphorus compounds // Biocatal. Biotransfor. 2007. V. 25, № 2-4. P. 359-364.

9. Вотчицева Ю.А., Ефременко Е.Н., Алиев Т.К. и др. Свойства гексагистицин-содержащей органофосфатгидролазы // Биохимия. 2006. Т. 76, № 2. C. $216-222$.

10. Benning M.M., Kuo J.M., Raushel F.M. et al. Three-dimensional structure of phosphotriesterase: an enzyme capable of detoxifying organophosphate nerve agents // J. Biochemistry. 1994. V. 33. P. 15001-15007.

11. Benning M.M., Kuo J.M., Raushel F.M. et al. Three-dimensional structure of the binuclear metal center of phosphotriesterase // J. Biochemistry. 1995. V. 34. P. 7973-7978.

12. Vanhooke J.L., Benning M.M., Raushel F.M. et al. Three-dimensional structure of the zinc-containing phosphotriesterase with the bound substrate analog diethyl 4-methylbenzylphosphonate // J. Biochemistry. 1996. V. 35. P. 6020-6025.

13.Ефременко Е.Н., Варфоломеев С.Д. Ферменты деструкции фосфорорганических нейротоксинов // Успехи биологической химии. 2004. Т. 44. С. 307-340.

14. Ефременко Е.Н., Лягин И.В., Гудков Д.А. и др. Иммобилизованные биокатализаторы на основе органофосфатгидролазы в процессах разложения ФОВ и продуктов их деструкции в различных объектах детоксификации // Теоретическая и прикладная экология. 2011. № 4. С. 26-31.

15. Sirotkina M., Lyagin I., Efremenko E. Hydrolysis of organophosphorous pesticides in soil: new opportunities with ecocompatible immobilized His $-\mathrm{OPH} / /$ Int. Biodeterior. Biodegradation. 2012. V. 68. P. $18-23$.

16. Патент РФ № 2525658 (2014).

17. Гайнуллина Э.Т., Гуликова Д.К., Понсов М.А et al. Антидоты против фосфорорганических токсикантов: проблемы и решения // Журнал Российского химического общества им. Д.И. Менделеева. 2010. T. LIV, № 4. C. 156-160.

18. Efremenko E., Lyagin I., Klyachko N. et al. A simple and highly effective catalytic nanozyme scavenger for organophosphorus neurotoxins // J. Controlled Release. 2017. V. 247. P. 175-181.

19. Патент РФ № 2615176 (2017).

20. Atsmon J., Brill-Almon E., Nadri-Shay C. et al. Preclinical and first-in-human evaluation of PRX105, a PEGylated plant-derived, recombinant human acetylcholinesterase // J. Toxicol. Appl. Pharmacology.
2015. V. 287. P. 202-209.

21. Masson P., Rochu B. Catalytic bioscavengers against toxic esters, an alternative approach for prophylaxis and treatments of poisonings // Acta Nature. 2009. № 1. P. 68-69.

22. Johnson J.L., Cusack B., Hu Ghes T.F. et al. Inhibitors tethered near the acetylcholinesterase active site serve as molecular rulers of the peripheral and acylation sites // J. Biol. Chem. 2003. V. 278. P. $38948-$ 38955.

23. Cusack B., Romanovskis P., Johnson J.I. et al. A novel strategy for protection against organophosphate toxicity: Evolution of cyclic inhibitors with high affinity for the acetylcholinesterase peripheral site // J. Chem. Biol. Interact. 2005. V. 157-158. P. 370-376.

24. Lenz D.E., Broomfield C.A., Masson P. // Chemical warfare agents: chemistry, pharmacology and therapeutics / Eds. Romano J.A., Luskey J.A., Salem H. Boca Raton: CRC Press, 2007. P. 175.

25. Huang Y.O. et. al. // Proc. Natl. Acad. Sci. USA. 2007. V. 104. P. 13603.

26. Ilyushin D., Haertley O.M., Bobik T.V. et al. Chemical polysialylation of human recombinant butyrylcholinesterase delivers a long-acting bioscavenger for nerve agents in vivo // Proc. Natl. Acad. Sci. USA. 2013. V. 110, № 4. 1243-1248. doi: 10.1073/pnas. 1211118110. Epub. 2013 Jan 7.

27. Millard C.B., Lockridge O. Broomfield C.A. Design and expression of organophosphorus acid anhydride hydrolase activity in human butyrylcholinesterase // J. Biochemistry. 1995. V. 34. P. $15925-15933$.

28. Millard C.B., Lockridge O,, Broomfield C.A. Organophosphorus acid anhydride hydrolase activity in human butyrylcholinesterase: synergy results in a somanase // J. Biochemistry. 1998. V. 37. P. 237-247.

29. Yao Y., Liu J., Zhan C.G. Why does the G117H mutation considerably improve the activity of human butyrylcholinesterase against sarin? Insights from quantum mechanical/molecular mechanical free energy calculations // J. Biochemistry. 2012. V. 51. P. 8980-8992.

30. Masson P., Nachon F., Broomfield C.A. et al. A collaborative endeavor to design cholinesterase-based catalytic scavengers against toxic organophosphorus esters // Chem. Biol. Interact. 2008. V. 175. P. 273-280.

31. Патент CIIIA №5689038 (1997).

32. Патент США №6403653 (2002).

33. Патент США № 6410603 (2002).

34. Патент США № 6642037 (2003).

35. Le Jeune K.E., Dravis B.S., Yang F. et al. Fighting nerve agent chemical weapons with enzyme technology // Ann. NY Acad. Sci. 1998. V. 864. P. 153-170.

36. Le Jeune K.E., Mesiano A.J., Bover S.B. et al. Dramatically stabilized phosphotriesterase-polymers for nerve agent degradation // J. Biotechnology and Bioengineering. 1997. V. 54. P. 105-114.

37. Le Jeune K.E., Wild J.R., Russel A.J. Nerve agents degraded by enzymatic foams // J. Nature. 1998. V. 395. P. 27-28. 
38. Havens P.L., Rase H.F. // Ind. Eng. Chem. Res. 1993. V. 32, № 10. P. 2254-2258.

39. Le Jeune K.E., Russell A.J. Biocatalytic nerve agent detoxification // J. Biotech. Bioengineering. 1999. V. 62, № 6. P. 659-665.

40. Патент США № 4781959 (1988).

41. Патент РФ № 2330717 (2008).

42. Ефременко Е.Н., Завьялов В.В., Завьялова Н.В. и др. Разрыв С-Р связи в фосфонатах под действием ферментных биокатализаторов // Теоретическая и прикладная экология. 2015. № 3. С. 47-54.

43. Efremenko E., Peregudov A., Kildeeva N. et al. // J. Biocatalysis Biotransformation. 2005. V. 23, № 2. P. 103-108.

44. Патент РФ № 2261911 (2005).

45. Caldwell S.R., Raushel F.M. Detoxification of organophosphate pesticides using a nylon based immobilized phosphotriesterase from Pseudomonas diminuta // Appl. Biochem. Biotechnol. 1991. V. 31. P. 59-72.

46. Caldwell S.R., Raushel F.M. Detoxification of organophosphate pesticides using animmobilized phosphotriesterase from Pseudomonas diminuta // J. Biotechnol. Bioengineering. 1991. V.37. P. 103-109.

47. Gill I., Ballesteros A. Degradation of organophosphorous nerve agents by enzyme-polymer nanocomposites: efficient biocatalytic materials for personal protection and large-scale detoxification // J. Biotechnol. Bioengineering. 2000. V. 70, № 4. P. 400-411.

48. Патент WO112482 (2004).

49. Mc Daniel C.S., Mc Daniel J., Wales M.E., Wild J.R. // Progress in Organic Coatings. 2006. V. 55. P. 182-188.

50. Sethunathan N., Yoshida T. // Can. J. Microbiol. 1973. V. 19. P. 873.

51. Munnecke D.M. Enzymatic hydrolysis of organophosphate insecticides, a possible pesticide disposal method // Appl. Environ. Microbiol. 1976. V. 32. P. 7-13.

52. Cüneyt M., Serdar C.M., Murdock D.C., Rohde M.F. Parathion hydrolase gene from Pseudomonas diminuta MG: subcloning, complete nucleotide sequence, and expression of the mature portion of the enzyme in Escherichia coli // J. BioTechnology. 1989. V. 7. P. 1151-1155.

53. Omburo G.A., Kuo J.M., Mullins L.S, et al. Characterization of the zinc binding site of bacterial phosphotriesterase // J. Biol. Chem. 1992. V. 267. P. 13278.

54. Варфоломеев С.Д., Курочкин И.Н., Райнина Е.И. и др. Новый технологический подход к уничтожению химического оружия. Полная биологическая деградация химических боеприпасов // Журнал российского химического общества им. Д.И. Менделеева. 1995. Т. 39, № 4. С. 20-24.

55. Харечко А.Т., Мягких В.И., Остроумов Ю.И. и др. Применение микроорганизмов для деструкции опасных веществ загрязняющих окружающую среду // Журнал российского химического общества им. Д.И. Менделеева. 1993. Т. 37, № 3. С. 30-43.

56. Боронин А.М., Сахаровский В.T., Старовойтов И.И. и др. Научные основы комплексной экологически безопасной технологии уничтожения иприта // Прикладная биохимия и микробиология. 1996. T. 32, № 1. C. 61-68.
57. Varfolomeyev S.D., Kurochkin I.N., Skliar V.I. et al. // Biocataletic degradation of chemical warfare related materials. Edgewood, 1995. P. 16.

58. Rainina E., Varfolomeyev S.D., Wild J.R. // Biocatalytic degradation of chemical warfare related materials. Edgewood, 1995. P. 9.

59. Харечко А.Т., Мягких В.И., Корякин Ю.Н. и др. Оценка влияния микроорганизмов на динамику разложения зомана в почве // Журнал российского химического общества им. Д.И. Менделеева. 1995. Т. 39, № 4. C. 104-107.

60. Funk S.B., Roberts D.J., Crawford D.J. et al. Initial phase optimization for bioremediation of munition compound-contaminated soils // Appl. Env. Microbiol. 1992. V. 59, № 7. P. 2171-2177.

61. Kaake R.H., Roberts D.J., Stevens T.O. et al. Bioremediation of soils contaminated with the herbicide 2-secbuty1-4, 6-dinitrophenol (dinoseb) // Appl. Env. Microbiol. 1990. V. 56, № 6. P. 1666-1671.

62. Howard J., Fox S. Review of current research projects and innovations in remediation // Gen. Eng. News. 1994. V. 14, № 17. P. 8-9.

63. Tursman J.F., Cork D.J. Subsurface contaminant bioremediation engineering // Crit. Rev. Env. Contr. 1992. V. 22, № 5. P. 1-26.

64. Biodegradation of chemical warfare agents: demilitarization applications. Edgewood, 1993.

65. Biocatalytic degradation of chemical warfare related materials. Edgewood, 1995.

66. De Frank J.J., Cheng Tu-Chen, Rolakowsky G.E. et al. Advances in the biodegradation of chemical warfare agents and related materials: Advances in the biodegradation of chemical warfare agents and related materials / Abstr. Keystone symp. Environ. Biotechnol. Lake Tahoe, Calif., March 16-22, 1995 // Cell. Biochem. 1995. V. 21a. P. 41.

67. Tu-Chen Cheng, Harvey S.P., Chen G.L. Cloning and expression of a gene encoding a bacterial enzyme for decontamination of organophosphorous nerve agents and nucleotide sequence of the enzyme // Appl. Env. Microbiol. 1996. V. 62. № 5. P. 1636-1641.

68. Dumas D.P. et al. Inactivation of organophosphorous nerve agents by the phosphotriesterase from Pseudomonas diminuta // Arch. Biochem. Biophys. 1990. V. 277, № 1. P. 155-159.

69. Dumas D.P. et al. Purification and properties of the phosphotriesterase from Pseudomonas diminuta // J. Biol. Chem. 1989. V. 264. P. 19655-19659.

70. Landis W.G. et al. Identification and comparison of the organophosphate acid anhydrase activations of the clam, Rangia cuneata // Comp. Biochim. Physiol. 1989. V. 94, № 2. P. 365-371.

71. Harvey S., De Frank J.J., Kamely D. et al. Microbiol degradation of agent orange and mustard related compounds // Biotechnology: bridging research and applications. Eds. Kamely D., Chakrabatry A.M., Komguti S.E. Dordrecht, Kluwer Acad. Pub., 1991. P. 221-230.

72. Ефременко Е.Н., Сироткина М.С., 
Завьялова Н.В. и др. Иммобилизованные гетерогенные биокатализаторы для разложения фосфорорганических отравляющих веществ // Вестник Российского университета дружбы народов. Серия: Экология и безопасность жизнедеятельности. 2011. № 1. С. 61-66.

73. Sirotkina M., Lyagin I., Efremenko E. Hydrolysis of organophosphorus pesticides in soil: New Opportunities with ecocomhatible immobilized His6 $\mathrm{OPH} / /$ International Biodeterioration \& Biodegradation. 2012. № 68. P. 18-23.

74. Патент РФ № 2451077 (2012).

75. Петров С.В., Корякин Ю.Н., Холстов В.И. и др. Биотехнология в решении проблемы уничтожения химического оружия // Журнал российского химического общества им. Д.И. Менделеева. 1995. Т. 39. № 4. С. 18-20.

76. Бакулин Ю.С., Завьялова Н.В., Харечко А.Т. и др. Экспериментальная проверка биодеструкции реакционных масс химической детоксикации ФОВ фосфонат-разлагающими бактериями// Федеральные и региональные проблемы уничтожения химического оружия. М.: 2000. С. 47-52.

77. Петров С.В., Холстов В.И., Завьялова Н.В. идр. Биодеградация фосфорорганических отравляющих веществ // Федеральные и региональные проблемы уничтожения химического оружия. М.: 1999. C. 51-60.

78. Kiernan V. Bacteria with a healthy appetite for mustard gas // J. New Sci. 1994. V. 141, № 1914. P. 10-11.

79. Landis W.G. et al. Alternative substrates and an inhibitor of the organophosphate acid anhidrase activities of the protozoan // Tetrahymena Thermophilia. Comp. Biochim. Physiol. 1989. № 2. P. 211-216.

80. Trapp R. SIPRI Chemical and Biological Warfare Studies. London, Philadelphia: Taylor and Fransis Ltd. 1985.

81. Attaway H., Nelson J.O., Baya A.M. et al. Bacterial detoxification of diisopropyl fluorophosphate // Appl. Environ. Microbiol. 1987. V. 53, № 7. P. $1685-1689$.

82. De Frank J.J., Cheng T.C. // J. Bacteriol. 1991. V. 173. P. 1938-1943.

83. Schowanek D., Verstraete W. Phosphonate utilization by bacterial cultures and enrichments from environmental samples // Appl. Environ. Microbiol. 1990. V. 56. P. 895-903.

84. Smith J.D. Metabolism of Phosphonates. The role of phosphonates in living systems / Ed. Hilderbrand, R.L., Boca Raton, CRC Press, 1983. P. 31-54.

85. Selvapandiyan A., Bhatnagar Raj K. Isolation of glyphosate-metabolising Pseudomonas: detection, partial purification and localization of carbon-phosphorus lyase // Appl. Microbiol. Biotechnol. 1994. V. 40. P. 876-882.

86. Shinabarger D.L., Braymer H.D. Glyphosate catabolism by Pseudomonas sp. strain PG2982 // J. Bacteriol. 1986. V. 168. P. 702-703.

87. Daughton C.G., Cook A.M., Alexander M. // J. Agric. Food. Chem. 1979. V. 27, № 6. P. 1375-1382.
88. Verwej A., Boter H.L. // Pestic. Sci. 1977. V. 7, № 3. P. 355-362.

89. Kaaijk J., Frijlink C. // Pestic. Sci. 1977. V. 8, № 4. P. 544-548.

90. Cook A.M., Daughton C.G., Alexander M. Benzene from bacterial cleavage of the carbonphosphorus bond of phenylphosphonates // Biochem. J. 1979. V. 184, № 3. P. 453-455.

91. Daughton C.G., Cook A.M., Alexander M. // FEMS Microbiol. Lett. 1989. V. 5, № 1. P. 91-93.

92. Матыс С.В., Лауринавичюс Л.С., Несмеянова М.А. Влияние условий культивирования на разложение метилфосфоновой кислоты клетками E.coli / Биотехнология защиты окружающей среды. Тезисы докладов конференции. Пущино. 1994. С. 13.

93. Wild J.R., Ruashel F.M. The genetic and biochemical manipulation of a broad-spectrum organophosphate degrading system / Report No: 24002 Ls U.S. Department of the Army Research office Funding 1990. No: DAAZ 03-87-0017.

94. Robinson J.P.P. Chemical Weapons: Destruction and Conversion (SPJRJ) Publ: Taylor, Francis, N.Y.: 1980. P. 9-56.

95. Penski E.C. TR - ARCSL - TR - 83021. AD B07518L Aberdeen Proving Ground, MD US Army, Res. Develop. Command. 1983.

96. Александров В.Н., Емельянов В.И. Отравляющие вещества. М.: 1990.

97. Ашихмина Т.Я. Научно-методологические основы системы комплексного экологического мониторинга объектов хранения и уничтожения химического оружия. Киров. 2001.

98. Савельева Е.И., Радилов А.С., Кузнецова Т.А. и др. Определение метилфосфоновой кислоты и ее эфиров как химических маркеров фосфорорганических отравляющих веществ // Журнал прикладной химии. 2001. Т. 74, № 10. С. 1677.

99. Савельева Е.И., Зенкевич И.Г., Кузнецова Т.А. и др. Исследование продуктов превращений фосфорорганических отравляющих веществ методом газовой хроматографии - масс-спектрометрии // Журнал российского химического общества им. Д.И. Менделеева. 2002. Т. 46, № 6. С. 89-92.

101. Shames S.L., Wackett L.P., La Barge M.S. et al. Fragmentative and stereo chemical isomerization probes for hemolytic carbon to phosphorus bond scission catalyzed by bacterial carbon-phosphorus lease // J. Bioorg. Chem. 1987. V. 15. P. 366-373.

102. Penski E.C. TR - ARCSL - TR - 83021. AD B07518L Aberdeen Proving Ground. MD: US Army Res. Develop. Command. 1983.

103. Small V.J. TR - 8202 (AD - B077 091) Fort Detrick. MD: US Army Med. Res. Develop. Command. 1983.

104. Биологическая дегазация отравляющих веществ. Материалы конференции научноисследовательских институтов НАТО. 1991. М. 1991.

105. Milstein O., Nicklas B., Huttermann A. Oxidation of aromatic compounds in organic solvents 
Reseach in the Sphere of Perspective Use of Biochemical and Medical Biocatalytic Technologies...

with lea case from Trametes vesicular // Appl. Microbiol. Biotechnology. 1989. V. 31. P. 70-74.

106. Clifford D., Lin C.C. // Government Rep. 1991.

V. 91. № 15. P. 124.

107. Kanel A. // J. Polytechn. 1990. № 5. P. 557-559.

108. Hackl R.P., Wright F.R. Bruynesteyn A. // Appl. Organometall. Chem. 1990. V. 4, № 4. P. 245-250.

109. Патент РФ № 2185901 (2002).

110. Рэуце К., Кырстя С. Борьба с загрязнением почвы М. 1986.

111. Авторское свидетепьство СССР № 513939 (1989).

112. Кузнецов С.И. Микрофлора озер и ее геохимическая деятельность. Л.: 1970.

113. Головлева Л.А. Деградация пестицидов микроорганизмами: биотехнологические аспекты проблемы // Микробиология очистки воды / Докл. 1 Всесоюзной конференции. Киев, 1982.

114. Леонова Л.И., Ступина В.В. Водоросли водоочистки сточных вод. Киев, 1990.

115. Тарасенко Н.Ф., Захарчук Р.В. Очистка сточных вод биоценозами микроводорослей и бактерий активного ила // Микробиология очистки воды. Киев. 1982.

116. Simonds M.A. Experience with algal bloom and the removal of phosphorus from sewage // J. Water Res. 1973. V. 7, № 1. P. 255-264.

117. Патентная заявка Франции № 2004566 (1969).

118. Патент США № 3716484 (1972).

119. Патентная заявка ФРГ № 2016798 (1970).

120. Патентная заявка Франции № 2043202 (1970).

121. Патент США № 3499837 (1967).

122. Патент США № 3725269 (1972).

123. Патентная заявка Франции № 2004566 (1969).

124. Патентная заявка США № 3617569 (1970).

125. Патентная заявка Франщии № 32009220 (1969).

126. Патентная заявка ФРГ № 1959652 (1968).

127. Авторское свидетельство СССР № 228210 (1984).

128. Авторское свидетельство СССР № 258499 (1985).

129. ОСТ В-84-2398-88. Биотестирование отраслевых сточных вод. Основные положения (1988).

130. ОСТ В-84-2399-88. Биотестирование отраслевых сточных вод. Методы анализа. 1988.

131. ЗавьяловаН.В. Филимонов И.В., Ефременко Е.Н. и др. Биотехнологические методы и нейтрализующие средства для обеззараживания и очищения почв и вод, загрязненных экотоксикантами // Теоретическая и прикладная экология. 2014. № 4. С. 26-33.

132. Завьялова Н.В. Филимонов И.В., Ковтун В.А. и др. Основные технологические операции и стадии биоремедиации почв и очистки вод in situ // Теоретическая и прикладная экология. 2014. № 4. С. 34--41.

133. Завьялова Н.В. Филимонов И.В., Е.Н. Ефременко Е.Н. и др. Биокатализаторы на основе штаммов микроорганизмов и ферментов, обладающих повышенной способностью к разложению отравляющих веществ и продуктов их деструкции, в процессе очистки почв и вод // Теоретическая и прикладная экология. 2014. № 4. С. 42-50.

134. Янковская А.А., Филимонов И.В.,
Завьялова Н.В. и др. Экологически безопасная биоремедиация почвы и воды in situ от продуктов деструкции отравляющих веществ // Теоретическая и прикладная экология. 2016. № 4. С. 89-95.

135. Стяжкин К.К., Туманов А.С., Ашихмина Т.Я. и др. Экспериментальная оценка микробоцидного и деградативного потенциала биопрепарата деструктора фосфорорганических соединений // Теоретическая и прикладная экология. 2014. № 4. С. 51-59.

136. Туманов А.С., Ашихмина Т.Я., Лещенко А.А. идр. Биопрепарат с расширенным спектром биодегративной активности для рекультивации почвы объекта уничтожения химического оружия // Теоретическая и прикладная экология. 2015. № 3. С. 61-69.

137. Стяжкин К.К., Петров С.В., Туманов А.С. и др. Биопрепарат для ремедиации почвы в пределах зоны защитных мероприятий объекта уничтожения химического оружия «Марадыковский» // Теоретическая и прикладная экология. 2013. № 4. С. 41-48.

138. Ефременко Е.Н., Лягин И.В., Гудков Д.А. и др. Комбинированное применение ферментного и бактериального биокатализаторов в процессах биодеструкции ФОВ и продуктов их разложения // Теоретическая и прикладная экология. 2015. № 3. С. 35-39.

139. Le Jeune K.E., Russell A.J. Biocatalytic nerve agent detoxification in firefighting foams // J. Biotechnology and Bioengineering. 1999. V. 62, № 6. P. 659-665.

140. Янковская А.А., Филимонов И.В., Завьялова Н.В. и др. Направления использования биотехнологических способов при ликвидации последствий работы объектов по уничтожению химического оружия // Теоретическая и прикладная экология. 2017. № 4. С. 66-72.

141. Уткин А.Ю., Либерман Б.М., Кондратьев В.Б. Математическое описание процессов детоксикации фосфорорганических отравляющих веществ // Журнал российского химического общества им. Д.И. Менделеева. 2007. T. LI, № 2. С. 12-18.

142. Патент РФ № 2352375 (2009).

143. Munro N.B., Talmage S.S., Griffin G.D. et al. The sources, fate, and toxicity of chemical warfare agent degradation products // Research Reviews. 1999. V. 107, № 12. P. 933-974.

144. Международная конвенция о запрещении разработки, производства, накопления иприменения химического оружия и о его уничтожении. ОЗХО, C.N. 2005.

145. Ефременко Е.Н., Завьялова Н.В., Гудков Д.А. и др. Экологически безопасная биодеградация реакционных масс, образующихся при уничтожении фосфорорганических отравляющих веществ // Журнал российского химического общества им. Д.И. Менделеева. 2010. Т. LIV, № 4. С. 19-24.

146. Патент РФ № 2408724 (2011).

147. Патент WO №01/56380 (2001).

148. Патент США №5589386 (1996).

149. Патент США №5928927 (1999).

150. Патент США № 6080566 (2000). 
151. Hoskin F.-C.G., Walker J.E., Dettbarn W.-D. et al. // Biochemical Pharmacology. 1995. V. 49, № 5. P. 711-715.

152. Rastogi V.K., De Frank J.J., Cheng T.-C. et al. // Biochem. Biophys. Res. Commun. 1997. V. 241, № 2. P. 294-296.

153. De Frank J.J, Guelta M., Harvey S. et al. // Enzymes in Actions: Green Solution for Chemical Problem / Eds. Zwanenburg B. et al. Netherlands: Kluver
Acad. Publ., 2000. P. 193-209.

154. Патент США № 7001758 B1 (2006).

155. Патент США № 6080906 (2000).

156. Патент США № 2203116 (2003).

157. Патент США № 6498281 (2002).

158. Патент РФ № 2296164 (2007).

159. Патент РФ № 2154103 (2000).

160. Патент РФ № 2360967 (2009).

161. Патент РФ № 2394910 (2010).

Об авторах

Федеральное государственное бюджетное учреждение «27 Научный центр» Министерства обороны Российской Федерации, 105005, г. Москва, Бригадирский переулок, д. 13

Филимонов Игорь Владимирович. Старший научньй сотрудник, канд. техн. наук.

Янковская Александра Анатольевна. Соискатель ученой степени канд. техн. наук.

Кужелко Сергей Владимирович. Старший офицер отдела.

Завьялов Василий Владимирович. Научный руководитель диссертации на соискание ученой степени канд. хим. наук Кужелко С.В., канд. хим. наук.

Завъялова Наталья Васильевна. Главный научный сотрудник, д-р биол. наук, проф., акад. АВН.

Голипад Александр Николаевич. Начальник управления, канд, техн. наук.

Колесников Диитрий Петрович. Заместитель начальника центра по научно-исследовательской работе, канд. техн. наук, доцент.

Ковтун Виктор Александрович. Началыник центра, канд. хим. наук, доцент.

Холстов Виктор Иванович. Член дис. совета на базе 27 НЦ МО РФ, д-р хим. наук, профессор.

Московский государственный университет имени М.В. Ломоносова, химический факультет, 119234, г. Москва, ул. Ленинские Горы, д. 1, стр. 3

Лягин Илья Владимирович. Старший научньй сотрудник, канд. хим. наук.

Еळременко Елена Николаевна. Зав. лабораторией, д-р биол. наук, профессор.

Адрес для переписки: Завьялова Наталья Васильевна; 27nc_1@mil.ru

\title{
RESEARCH IN THE SPHERE OF PERSPECTIVE USE OF BIOCHEMICAL AND MEDICAL BIOCATALYTIC TECHNOLOGIES IN THE INTERESTS OF ARMED FORCES
}

\author{
I.V. Filimonov ${ }^{1}$, A.A. Yankovskaya ${ }^{1}$, S.V. Kuzhelko ${ }^{1}$, V.V. Zavyalov ${ }^{1}$, N.V. Zavyalova ${ }^{1}$,
} A.N. Golipad ${ }^{1}$, D.P. Kolesnikov¹, V.A. Kovtun ${ }^{1}$, V.I. Kholstov ${ }^{1}$, I.V. Lyagin², E.N. Efremenko²

${ }^{1}$ Federal State Budgetary Establishment "27 Scientific Centre» of the Ministry of Defence of the Russian Federation, Brigadirskii Lane 13, Moscow 105005, Russian Federation ${ }^{2}$ Lomonosov Moscow State University, Faculty of Chemistry, Leninskie Gory 1-3, Moscow 119234, Russian Federation 
The article is dedicated to the review of the theoretical and experimental research of the Russian and foreign scientists in the enzymes both in native state and in forms of chemically stabilized nanosized particles, promising for the development of military products of different types. It summarises the results of use of biocatalysts on the basis of enzymes and microorganisms-destructors for the neutralization of eco-toxicants. The nature of enzymes is analyzed. The significant part of the article is dedicated to the data obtained regarding the sphere of biochemical and medical biocatalytic technologies for the development of enzymatic prophylactic and therapeutic means. A special attention is paid to the enzymes, used in protective equipment, to environmental biocatalysts, to biopharmaceuticals on the basis of enzymes and microorganisms-destructors for the utilization of reaction masses, to chemical detoxification of poisonous substances. The authors point out the main trends in the further research in the sphere of biotechnologies: enzymatic pharmaceuticals for prophylaxis and treatment of OP poisoning; enzymes in self-degassing materials and in protective equipment; biocatalysts for soil, water and surface purification; biopharmaceuticals on the basis of enzymes and microorganisms-destructors for the degradation of reaction masses of toxic chemicals.

Keywords: bacteria Pseudomonas sp. 78G; environmental biocatalysts; hexahistidine-tagged organophosphate hydrolase (His_-OPH); microorganisms-destructors of toxic chemicals; selfdegassing materials; biocatalysts of chemical reactions in organism; enzymatic antidotes of $O P$ substances; enzymatic components of protective equipment; enzymatic catalysts of the destruction of the reaction masses of $O P$ substances; organophosphorus $(O P)$ toxic chemicals.

For citation: Filimonov I.V., Yankovskaya A.A., Kuzhelko S.V., Zavyalov V.V., Zavyalova N.V., Golipad A.N., Kolesnikov D.P., Kovtun V.A., Kholstov V.I., Lyagin I.V., Efremenko E.N. Research in the Sphere of Perspective Use of Biochemical and Medical Biocatalytic Technologies in the Interests of Armed Forces // Journal of NBC Protection Corps. 2018. V. 2. № 2. P. 18-50.

\section{Conflict of interest statement}

The authors declare that the research was conducted in the absence of any commercial or financial relationship that could be construed as a potential conflict of interest.

\section{Peer review information}

The article has been peer reviewed by two experts in the respective field. Peer reviews are available from the Editorial Board.

\section{CONTENTS}

Enzymes' nature

Use of biocatalysts on the basis of enzymes and microorganisms-destructors for the neutralization of eco-toxicants

IModern research in the sphere of development of enzymatic antidotes of OP substances

II Enzymatic components of protective equipment

III. Environmental biocatalysts

IV Biopharmaceuticals on the basis of enzymes and microorganisms-destructors for the utilization of reaction masses, obtained after the chemical detoxification of poisonous substances

Main trends in research on perspective use of biopharmaceuticals during military products development

1 Enzymatic antidotes

2 Enzymes in self-degassing materials as components of protective equipment

3 Environmental biocatalysts

4 Biopharmaceuticals on the basis of enzymes and microorganisms-destructors for the utilization of reaction masses of toxic chemicals

Conclusion

Conflict of interest statement

Peer review information

References 
I.V. Filimonov, A.A. Yankovskaya, S.V. Kuzhelko et al.

\section{References}

1. White A., Handler F., Smith E. et al. Principles of biochemistry. Moscow: 1981 (in Russian).

2. Varfolomeyev S.D. Biokinetics. Moscow: 1999 (in Russian).

3. Physical chemistry of bioprocesses / Ed. Varfolomeyev S.D. Moscow: 2014 (in Russian).

4. Human molecular polymorphism (in 2 Vols) /

Ed. Varfolomeyev S.D. Moscow: 2007 (in Russian).

5. Efremenko E.N., Sergeeva V.S. Organophosphate hydrolase - an enzyme catalyzing degradation of phosphorus-containing toxins and pesticides // Russian Chemical Bulletin. 2001. V. 50. № 10. P. 1743-1749 (in Russian).

6. Efremenko E.N., Lyagin I.V., Zavyalov V.V. et al. Enzymes in the technology of destruction of organophosphorus toxic substances // Mendeleev Chemistry Journal. 2007. V. LI, № 2. P. 24-29 (in Russian).

7. Efremenko E., Votchitseva Y., Plieva F. et al. Purification of His6-organophosphate hydrolase using monolithic supermacroporous polyacrylamide cryogels developed for immobilized metal affinity chromatography // Appl. Microbiol. Biotech. 2006. V. 70, № 5. P. 558-563.

8. Efremenko E., Lyagin I., Gudkov D. et al. Immobilized biocatalysts for detoxification of neurotoxic organophosphorus compounds // Biocatal. Biotransfor. 2007. V. 25, № 2-4. P. 359-364.

9. Votchitseva Yu. A., Efremenko E.N., Aliyev T.K. et al. Properties of hexahistidinetagged organophosphate hydrolase // Biochemistry. 2006. V. 76, № 2. P. 216-222 (in Russian).

10. Benning M.M., Kuo J.M., Raushel F.M. et al. Three-dimensional structure of phosphotriesterase: an enzyme capable of detoxifying organophosphate nerve agents // J. Biochemistry. 1994. V. 33. P. 15001-15007.

11. Benning M.M., Kuo J.M., Raushel F.M. et al. Three-dimensional structure of the binuclear metal center of phosphotriesterase // J. Biochemistry. 1995. V. 34. P. 7973-7978.

12. Vanhooke J.L., Benning M.M., Raushel F.M. et al. Three-dimensional structure of the zinc-containing phosphotriesterase with the bound substrate analog diethyl 4-methylbenzylphosphonate // J. Biochemistry. 1996. V. 35. P. 6020-6025.

13. Efremenko E.N., Varfolomeyev S.D. Enzymes of degradation of organophosphorus neurotoxins // Biology and Chemistry Achievement. 2004. V. 44. P. 307-340 (in Russian).

14. Efremenko E.N., Lyagin I.V., Gudkov D.A. et al. Immobilized biocatalysts on the basis of organophosphorous in the process of decomposition of organophosphorus toxic substances // Theoretical and applied ecology. 2011. No. 4. P. 26-31 (in Russian).

15. Sirotkina M., Lyagin I., Efremenko E. Hydrolysis of organophosphorous pesticides in soil: new opportunities with ecocompatible immobilized His6-OPH // Int. Biodeterior. Biodegradation. 2012. V. 68. P. 18-23 (in Russian).
16. Patent RU № 2525658 (2014) (in Russian).

17. Gainullina E.T., Gulikova D.K., Ponsov M.A. et al. Antidotes against phosphororganus toxicants: problems and decisions // Mendeleev Chemistry Journal. 2010. V. LIV, № 4. P. 156-160 (in Russian).

18. Efremenko E., Lyagin I., Klyachko N. et al. A simple and highly effective catalytic nanozyme scavenger for organophosphorus neurotoxins // J. Controlled Release. 2017. V. 247. P. 175-181 (in Russian).

19. Patent RU № 2615176 (2017) (in Russian).

20. Atsmon J., Brill-Almon E., Nadri-Shay C. et al. Preclinical and first-in-human evaluation of PRX105, a PEGylated plant-derived, recombinant human acetylcholinesterase // J. Toxicol. Appl. Pharmacology. 2015. V. 287. P. 202-209.

21. Masson P., Rochu B. Catalytic bioscavengers against toxic esters, an alternative approach for prophylaxis and treatments of poisonings // Acta Nature. 2009. № 1. P. 68-69.

22. Johnson J.L., Cusack B., Hu Ghes T.F. et al. Inhibitors tethered near the acetylcholinesterase active site serve as molecular rulers of the peripheral and acylation sites // J. Biol. Chem. 2003. V. 278. P. 3894838955.

23. Cusack B., Romanovskis P., Johnson J.I. et al. A novel strategy for protection against organophosphate toxicity: Evolution of cyclic inhibitors with high affinity for the acetylcholinesterase peripheral site // J. Chem. Biol. Interact. 2005. V. 157-158. P. 370-376.

24. Lenz D.E., Broomfield C.A., Masson P. // Chemical warfare agents: chemistry, pharmacology and therapeutics / Eds. Romano J.A., Luskey J.A., Salem H. Boca Raton: CRC Press, 2007. P. 175.

25. Huang Y.O. et. al. // Proc. Natl. Acad. Sci. USA. 2007. V. 104. P. 13603.

26. Ilyushin D., Haertley O.M., Bobik T.V. et al. Chemical polysialylation of human recombinant butyrylcholinesterase delivers a long-acting bioscavenger for nerve agents in vivo // Proc. Natl. Acad. Sci. USA. 2013. V. 110, № 4. 1243-1248. doi: 10.1073/pnas. 1211118110 . Epub. 2013 Jan 7.

27. Millard C.B., Lockridge O. Broomfield C.A. Design and expression of organophosphorus acid anhydride hydrolase activity in human butyrylcholinesterase // J. Biochemistry. 1995. V. 34. P. $15925-15933$.

28. Millard C.B., Lockridge O., Broomfield C.A. Organophosphorus acid anhydride hydrolase activity in human butyrylcholinesterase: synergy results in a somanase // J. Biochemistry. 1998. V. 37. P. 237-247.

29. Yao Y., Liu J., Zhan C.G. Why does the G117H mutation considerably improve the activity of human butyrylcholinesterase against sarin? Insights from quantum mechanical/molecular mechanical free energy calculations // J. Biochemistry. 2012. V. 51. P. 8980-8992.

30. Masson P., Nachon F., Broomfield C.A. et al. A collaborative endeavor to design cholinesterase-based catalytic scavengers against toxic organophosphorus esters // Chem. Biol. Interact. 2008. V. 175. P. 273-280. 
31. Patent US №5689038 (1997).

32. Patent US №6403653 (2002).

33. Patent US № 6410603 (2002).

34. Patent US № 6642037 (2003).

35. Le Jeune K.E., Dravis B.S., Yang F. et al. Fighting nerve agent chemical weapons with enzyme technology // Ann. NY Acad. Sci. 1998. V. 864. P. 153-170.

36. Le Jeune K.E., Mesiano A.J., Bover S.B. et al. Dramatically stabilized phosphotriesterase-polymers for nerve agent degradation // J. Biotechnol. Bioengineering. 1997. V. 54. P. $105-114$.

37. Le Jeune K.E., Wild J.R., Russel A.J. Nerve agents degraded by enzymatic foams // J. Nature. 1998. V. 395. P. 27-28.

38. Havens P.L., Rase H.F. // Ind. Eng. Chem. Res. 1993. V. 32, № 10. P. 2254-2258.

39. Le Jeune K.E., Russell A.J. Biocatalytic nerve agent detoxification // J. Biotech. Bioengineering. 1999. V. 62, № 6. P. 659-665.

40. Patent US № 4781959 (1988).

41. Patent RU № 2330717 (2008) (in Russian).

42. Efremenko E.N., Zavyalov V.V., Zavyalova N.V. et al. Cleavage of C-P bond in phosphonates under the action of enzymatic biocatalysts // Theoretical and applied ecology. 2015. № 3. P. 47-54 (in Russian).

43. Efremenko E., Peregudov A., Kildeeva N. et al. // J. Biocatal. Biotransform. 2005. V. 23, № 2. P. 103-108 (in Russian).

44. Patent RU № 2261911 (2005) (in Russian).

45. Caldwell S.R., Raushel F.M. Detoxification of organophosphate pesticides using a nylon based immobilized phosphotriesterase from Pseudomonas diminuta // Appl. Biochem. Biotechnol. 1991. V. 31.P. 59-72.

46. Caldwell S.R., Raushel F.M. Detoxification of organophosphate pesticides using animmobilized phosphotriesterase from Pseudomonas diminuta // J. Biotechnol. Bioengineering. 1991. V. 37. P. 103-109.

47. Gill I., Ballesteros A. Degradation of organophosphorous nerve agents by enzyme-polymer nanocomposites: efficient biocatalytic materials for personal protection and large-scale detoxification // J. Biotechnol. Bioengineering. 2000. V. 70, № 4. P. 400-411.

48. Patent WO112482 (2004).

49. Mc Daniel C.S., Mc Daniel J., Wales M.E., Wild J.R. // Progress in Organic Coatings. 2006. V. 55. P. 182-188. 50. Sethunathan N., Yoshida T. // Can. J. Microbiol. 1973. V. 19. P. 873.

51. Munnecke D.M. Enzymatic hydrolysis of organophosphate insecticides, a possible pesticide disposal method // Appl. Environ. Microbiol. 1976. V. 32. P. 7-13.

52. Cüneyt M., Serdar C.M., Murdock D.C., Rohde M.F. Parathion hydrolase gene from Pseudomonas diminuta MG: subcloning, complete nucleotide sequence, and expression of the mature portion of the enzyme in Escherichia coli // J. Bio Technology. 1989. V. 7. P. $1151-1155$.

53. Omburo G.A., Kuo J.M., Mullins L.S. et al. Characterization of the zinc binding site of bacterial phosphotriesterase // J. Biol. Chem. 1992. V. 267. P. 13278.

54. Varfolomeev S.D., Kurochkin I.N., Rainin E.I. et al. A new technological approach to chemical weapons destruction. Complete biological degradation of chemical munitions // RHZH. 1995. V. 39. № 4. P. 20-24 (in Russian).

55. Kharechko A.T., Myagkikh V.I., Ostroumov Yu.I. et al. The use of microorganisms for destruction of hazardous substances polluting // RHZH. 1993. V. 37. № 3. P. 40-43 (in Russian).

56. Boronin A.M., Sakharovskiy V.T., Starovoytov I.I. et al. Scientific bases of complex environmentally friendly technologies for mustard gas destruction // Appl. Biochem. Microbiol. 1996. V. 32. № 1. P. 61-68 (in Russian).

57. Varfolomeyev S.D., Kurochkin I.N., Skliar V.I. et al. // Biocataletic degradation of chemical warfare related materials. Edgewood, 1995. P. 16.

58. Rainina E., Varfolomeyev S.D., Wild J.R. // Biocatalytic degradation of chemical warfare related materials. Edgewood, 1995. P. 9.

59. Kharechko A.T., Myagkikh V.I., Koriakin Y.N. et al. Evaluation of the impact on the dynamics of microbial decomposition of soman in soil // RHZH. 1995. V. 39, № 4. P. 104-107 (in Russian).

60. Funk S.B., Roberts D.J., Crawford D.J. et al. Initial phase optimization for bioremediation of munition compound-contaminated soils // Appl. Env. Microbiol. 1992. V. 59, № 7. P. 2171-2177.

61. Kaake R.H., Roberts D.J., Stevens T.O. et al. Bioremediation of soils contaminated with the herbicide 2-secbuty1-4, 6-dinitrophenol (dinoseb) // Appl. Env. Microbiol. 1990. V. 56, № 6. P. 1666-1671.

62. Howard J., Fox S. Review of current research projects and innovations in remediation // Gen. Eng. News. 1994. V. 14, № 17. P. 8-9.

63. Tursman J.F., Cork D.J. Subsurface contaminant bioremediation engineering // Crit. Rev. Env. Contr. 1992. V. 22, № 5. P. 1-26.

64. Biodegradation of chemical warfare agents: demilitarization applications. Edgewood, 1993.

65. Biocatalytic degradation of chemical warfare related materials. Edgewood, 1995.

66. De Frank J.J., Cheng Tu-Chen, Rolakowsky G.E. et al. Advances in the biodegradation of chemical warfare agents and related materials: Advances in the biodegradation of chemical warfare agents and related materials / Abstr. Keystone symp. Environ. Biotechnol. Lake Tahoe, Calif., March 16-22, 1995 // Cell. Biochem. 1995. V. 21a. P. 41.

67. Tu-Chen Cheng, Harvey S.P., Chen G.L. Cloning and expression of a gene encoding a bacterial enzyme for decontamination of organophosphorous nerve agents and nucleotide sequence of the enzyme // Appl. Env. Microbiol. 1996. V. 62. № 5. P. 1636-1641.

68. Dumas D.P. et al. Inactivation of organophosphorous nerve agents by the phosphotriesterase from Pseudomonas diminuta // Arch. 
Biochem. Biophys. 1990. V. 277, № 1. P. 155-159.

69. Dumas D.P. et al. Purification and properties of the phosphotriesterase from Pseudomonas diminuta // J. Biol. Chem. 1989. V. 264. P. 19655-19659.

70. Landis W.G. et al. Identification and comparison of the organophosphate acid anhydrase activations of the clam, Rangia cuneata // Comp. Biochim. Physiol. 1989. V. 94, № 2. P. 365-371.

71. Harvey S., De Frank J.J., Kamely D. et al. Microbiol degradation of agent orange and mustard related compounds // Biotechnology: bridging research and applications / Eds. Kamely D., Chakrabatry A.M., Komguti S.E. Dordrecht, Kluwer Acad. Pub., 1991. P. 221-230.

72. Efremenko E.N., Sirotkin M.S., Zavyalov N.V. et al. Immobilized biocatalysts for heterogeneous decomposition of organophosphorus agents // Bulletin of the Russian People's Friendship University. Series: Ecology and life safety. 2011. № 1. P. 61-66 (in Russian).

73. Sirotkina M., Lyagin I., Efremenko E. Hydrolysis of organophosphorus pesticides in soil: New Opportunities with ecocomhatible immobilized His ${ }_{6}$ OPH// International Biodeterioration \& Biodegradation. 2012. № 68. P. 18-23.

74. Patent RU № 2451077 (2012) (in Russian).

75. Petrov S.V., Koriakin Yu.N., Kholstov V.I. et al. Biotechnology in chemical weapons destruction // RHZH. 1995. V. 39. № 4. P. 18-20 (in Russian).

76. Bakulin Yu.S., Zavyalova N.V., Kharechko A.T., Kholstov V.I. et al. Experimental verification of biodegradation of reaction mass of chemical detoxification of FEV phosphonate-degrading bacteria // Federal and regional issues of chemical weapons destruction. Moscow: VINITI, Release № 2. 2000. P. 47 52 (in Russian).

77. Petrov S.V., Kholstov V.I., Zavyalova N.V. et al. Biodegradation of organophosphorus agents // Federal and regional issues of chemical weapons destruction. Moscow: VINITI, release № 1. 1999. P. 51-60 (in Russian).

78. Kiernan V. Bacteria with a healthy appetite for mustard gas // J. New Sci. 1994. V. 141, № 1914. P. 10-11.

79. Landis W.G. et al. Alternative substrates and an inhibitor of the organophosphate acid anhidrase activities of the protozoan // Tetrahymena Thermophilia. Comp. Biochim. Physiol. 1989. № 2. P. 211-216.

80. Trapp R. SIPRI Chemical and Biological Warfare Studies. London, Philadelphia: Taylor and Fransis Ltd. 1985.

81. Attaway H., Nelson J.O., Baya A.M. et al. Bacterial detoxification of diisopropyl fluorophosphate // Appl. Environ. Microbiol. 1987. V. 53, № 7. P. $1685-1689$.

82. De Frank J.J., Cheng T.C. // J. Bacteriol. 1991. V. 173. P. $1938-1943$.

83. Schowanek D., Verstraete W. Phosphonate utilization by bacterial cultures and enrichments from environmental samples // Appl. Environ. Microbiol. 1990. V. 56. P. 895-903.
84. Smith J.D. Metabolism of phosphonates. The role of phosphonates in living systems / Ed. Hilderbrand, R.L., Boca Raton, CRC Press, 1983. P. 31-54.

85. Selvapandiyan A., Bhatnagar Raj K. Isolation of glyphosate-metabolising Pseudomonas: detection, partial purification and localization of carbon-phosphorus lyase // Appl. Microbiol. Biotechnol. 1994. V. 40. P. 876-882.

86. Shinabarger D.L., Braymer H.D. Glyphosate catabolism by Pseudomonas sp. strain PG2982 // J. Bacteriol. 1986. V. 168. P. 702-703.

87. Daughton C.G., Cook A.M., Alexander M. // J. Agric. Food. Chem. 1979. V. 27, № 6. P. 1375-1382.

88. Verwej A., Boter H.L. // Pestic. Sci. 1977. V. 7, № 3. P. $355-362$.

89. Kaaijk J., Frijlink C. // Pestic. Sci. 1977. V. 8, № 4. P. 544-548.

90. Cook A.M., Daughton C.G., Alexander M. Benzene from bacterial cleavage of the carbonphosphorus bond of phenylphosphonates // Biochem. J. 1979. V. 184, № 3. P. 453-455.

91. Daughton C.G., Cook A.M., Alexander M. // FEMS Microbiol. Lett. 1989. V. 5, № 1. P. 91-93.

92. Matys S.V., Laurinavičius L.S., Nesmeyanova M.A. Influence of culture conditions on decomposition of methylphosphonic acid with $E$. coli cells. // Environmental Biotechnology: Proc. rep. Pushchino .: 1994. P. 13 (in Russian).

93. Wild J.R., Ruashel F.M. The genetic and biochemical manipulation of a broad-spectrum organophosphate degrading system / Report No: 24002Ls U.S. Department of the Army Research office Funding 1990. No: DAAZ 03-87-0017.

94. Robinson J.P.P. Chemical weapons: destruction and conversion (SPJRJ). N.Y. Publ: Taylor, Francis: 1980. P. $9-56$.

95. Penski E.C. TR - ARCSL - TR - 83021. AD B07518L Aberdeen Proving Ground, MD US Army, Res. Develop. Command. 1983.

96. Alexandrov V.N., Emelyanov V.I. Toxic substances. Moscow: Military Publishing, 1990 (in Russian).

97. Ashikhmina T.Ya. Scientific and methodological basis of the system of complex ecological monitoring of chemical weapons storage and destruction plants. Kirov: Vyatka, 2001 (in Russian).

98. Savelyeva E.I., Radilov A.S., Kuznetsova T.A. et al. Determination of methylphosphonic acid and its esters as chemical markers of organophosphorus agents // J. Appl. Chem. 2001. V. 74. № 10. P. 1677 (in Russian).

99. Savelyeva E.I., Zenkevich I.G., Kuznetsova T.A. et al. Study of the products of transformation of organophosphorus compounds with gas chromatography - mass spectrometry // RHZH. 2002. V. 46. № 6. P. 89-92 (in Russian).

101. Shames S.L., Wackett L.P., La Barge M.S. et al. Fragmentative and stereo chemical isomerization probes for hemolytic carbon to phosphorus bond scission catalyzed by bacterial carbon-phosphorus lease // J. Bioorg. Chem. 1987. V. 15. P. 366-373. 
102. Penski E.C. TR - ARCSL - TR - 83021. AD B07518L Aberdeen Proving Ground. MD: US Army Res. Develop. Command. 1983.

103. Small V.J. TR - 8202 (AD - B077 091) Fort Detrick. MD: US Army Med. Res. Develop. Command. 1983.

104. Biological degasation of chemical weapons. Conference materials of scientific research institutes of NATO. M., 1991 (in Russian).

105. Milstein O., Nicklas B., Huttermann A. Oxidation of aromatic compounds in organic solvents with lea case from Trametes vesicular // Appl. Microbiol. Biotechnology. 1989. V. 31. P. 70-74.

106. Clifford D., Lin C.C. // Government Rep. 1991.

V. 91 . № 15. P. 124.

107. Kanel A. // J. Polytechn. 1990. № 5. P. 557-559.

108. Hackl R.P., Wright F.R. Bruynesteyn A. //

Appl. Organometall. Chem. 1990. V. 4, № 4. P. 245-250.

109. Patent RU № 2185901 (2002) (in Russian).

110. Reutse K. Pollution of soil. M.: Chemistry, 1986 (in Russian).

111. Author's Certificate USSR № 513939 (1989).

112. Kuznetsov S.I. Microflora of lakes and geochemical activity L.: Science, 1970 (in Russian).

113. Golovleva L.A. Degradation of pesticides by microorganisms: Biotechnological aspects // Microbiology water purification: Proc. 1 All-Union rep. Conf. Kiev: N. Dumka, 1982 (in Russian).

114. Leonova L.I. Stupina V.V. Algae purification of wastewater. Kiev: N. Dumka, 1990 (in Russian).

115. Tarasenko N.F., Zakharchuk RV. Wastewater purification with biocenoses of microalgae and bacteria // Microbiology of activated sludge of water purification. Kiev: Science. Dumka, 1982 (in Russian).

116. Simonds M.A. Experience with algal bloom and the removal of phosphorus from sewage // J. Water Res. 1973. V. 7, № 1. P. 255-264.

117. Patent application France № 2004566 (1969).

118. Patent US № 3716484 (1972).

119. Patent application GE № 2016798 (1970).

120. Patent application France № 2043202 (1970).

121. Patent US № 3499837 (1967).

122. Patent US № 3725269 (1972).

123. Patent application France № 2004566 (1969).

124. Patent application US № 3617569 (1970).

125. Patent application France № 32009220 (1969).

126. Patent application GE № 1959652 (1968).

127. Author's Certificate USSR № 228210 (1984) (in Russian).

128. Author's Certificate USSR № 258499 (1985) (in Russian).

129. OST B-84-2398-88. Biotesting industry wastewater. The main provisions (1988) (in Russian).

130. OST B-84-2399-88. Biotesting industry wastewater. Methods of analysis (1988) (in Russian).

131. Zavyalova N.V., Filimonov I.V., Yefremenko Ye.N., et al. Biotechnological methods and neutralizing agents for decontamination of soil and water treatment, polluted with ecotoxicants // Theoretical and applied ecology. 2014. № 4. P. 26-33 (in Russian).

132. Zavyalova N.V., Filimonov I.V., Kovtun V.A. et al. The main technological operations and stages of bioremediation of soils and water purification in situ // Theoretical and applied ecology. 2014. V. 4. C. 34-41 (in Russian).

133. Zavyalova N.V., Filimonov I.V., Yefremenko Ye.N.etal.Biocatalysts based on strains of microorganisms and enzymes having an increased ability to degrade toxic substances and their degradation products during cleaning of soils and waters // Theoretical and applied ecology. 2014. № 4. P. 42-50 (in Russian).

134. Yankovskaya A.A., Filimonov I.V., Zavyalova N.V. et al. Ecologically safe bioremediation of soil and water purification in situ from chemical warfare agents destruction products // Theoretical and applied ecology. 2016. V. 4. C. 89-95 (in Russian).

135. Styazhkin K.K., Tumanov A.S., Ashikhmina T.Ya. et al. Experimental Assessing microbicidal and degradation potential of the biological product, organophosphorus compounds destructor // Theoretical and applied ecology. 2014. V. 4. P. 51-59 (in Russian).

136. Tumanov A.S., Ashikhmina T.Ya., Leschenko A.A. et al. Bio-preparation with a broad spectrum of bio-degradative activity for soil remediation in the chemical weapons destruction plant "Maradykovsky" // Theoretical and applied ecology. 2015. V. 3. C. 61-69 (in Russian).

137. Styazhkin K.K., Petrov S.V., Tumanov A.S. et al. Biological product for soil remediation within the zone of protective measures of the chemical weapons destruction plant «Maradykovsky» // Theoretical and applied ecology. 2013. V. 4. P. 41-48 (in Russian).

138. Efremenko E.N., Lyagin I.V., Gudkov D.A. Combined application of enzymatic and bacterial biocatalysts in the processes of biodegradation of organophosphorous chemical warfare agents and products of their destruction // Theoretical and applied ecology. 2015. V. 3. P. 35-39 (in Russian).

139. Le Jeune K.E., Russell A.J. Biocatalytic nerve agent detoxification in firefighting foams // J. Biotechnol. Bioengineering. 1999. V. 62, № 6. P. 659-665.

140. Yankovskaya A.A., Filimonov I.V., Zavyalova N.V.etal. Directions for use of biotechnological methods of liquidating the consequences of chemical weapons destruction // Theoretical and applied ecology. 2017. V. 4. P. 66-72 (in Russian).

141. Utkin A.Yu., Lieberman B.M., Kondratyev V.B. et al. Mathematical description of organophosphorus poisons detoxication // Russian Chemical Journal. 2007. V. L (2). N 2. P. 12-18 (in Russian).

142. Patent RU № 2352375 (2009) (in Russian).

143. Munro N.B., Talmage S.S., Griffin G.D. et al. The sources, fate, and toxicity of chemical warfare agent degradation products // Research Reviews. 1999. V. 107, № 12. P. 933-974.

144. The Convention on the prohibition of the development, production, stockpiling and use of chemical weapons and on their destruction. OPCW, C.N. 2005. 
145. Efremenko E.N., Zavyalova N.V., Gudkov D.A. et al. Environmentally safe biodegradation of reaction mass formed at destruction of organophosphorus agents // Russian Chemical Journal. 2010. V. 4. P. 19-24 (in Russian).

146. Patent RU № 2408724 (2011) (in Russian).

147. Patent WO No01/56380 (2001).

148. Patent US №5589386 (1996).

149. Patent US №5928927 (1999).

150. Patent US № 6080566 (2000).

151. Hoskin F.-C.G., Walker J.E, Dettbarn W.-D. et al. // Biochem. Pharmacol. 1995. V. 49, № 5. P. 711-715.

152. Rastogi V.K., De Frank J.J., Cheng T.-C. et al.
// Biochem. Biophys. Res. Commun. 1997. V. 241, № 2. P. 294-296.

153. De Frank J.J, Guelta M., Harvey S. et al. // Enzymes in actions: green solution for chemical problem / Eds. Zwanenburg B. et al. Netherlands: Kluver Acad. Publ., 2000. P. 193-209. 154. Patent US № 7001758 B1 (2006). 155. Patent US № 6080906 (2000). 156. Patent US № 2203116 (2003). 157. Patent US № 6498281 (2002). 158. Patent RU № 2296164 (2007) (in Russian). 159. Patent RU № 2154103 (2000) (in Russian). 160. Patent RU № 2360967 (2009) (in Russian). 161. Patent RU № 2394910 (2010) (in Russian).

Authors

Federal State Budgetary Establishment «27 Scientific Centre» of the Ministry of Defence of the Russian Federation. Brigadirskii Lane 13, Moscow 105005, Russian Federation

Filimonov I.V. Senior Researcher. Candidate of Technical Sciences.

Yankovskaya A.A. Applicant for a Degree, Candidate of Technical Sciences.

Kuzhelko S.V. Senior Officer of the Department.

Zavyalov V.V. Candidate of Chemical Sciences.

Zavyalova N.V. Leading Researcher. Doctor of Biological Sciences, Professor, Academician of the Academy of Military Sciences.

Golipad A.N. Chief of the Department. Candidate of Technical Sciences.

Kolesnikov D.P. Deputy Head of the Centre. Candidate of Technical Sciences, Associate Professor.

Kovtun V.A. Head of the Centre. Candidate of Chemical Sciences, Associate Professor.

Kholstov V.I. Member of Dissertation Council of the 27 Scientific Centre of the Ministry of Defence of the Russian Federation. Doctor of Chemical Sciences, Professor.

Lomonosov Moscow State University, Faculty of Chemistry. Leninskie Gory 1-3, Moscow 119234, Russian Federation. Lyagin I.V. Senior Researcher. Candidate of Chemical Sciences.

Yefremenko Ye.N. Laboratory Chief. Doctor of Biological Sciences, Professor.

Adress: Zavyalova Natalya Vasilyevna; 27nc_1@mil.ru 